\title{
Palynofacies classification of the depositional elements of confined turbidite systems: examples from the Gres d'Annot, SE France
}

McArthur, A.D. ${ }^{1}$, Kneller, B.C. ${ }^{2}$, Wakefield, M.I. ${ }^{3}$, Souza, P.A. ${ }^{1}$, Kuchle, J. ${ }^{1}$

\author{
1. Instituto de Geociências, Universidade Federal do Rio Grande do Sul, Porto Alegre, RS 91501-970, Brazil \\ (adam.mcarthur@ufrgs.br) \\ 2. Department of Geology \& Petroleum Geology, University of Aberdeen, Aberdeen, AB24 3UE, UK \\ 3. BG Group, Geoscience Studies Team, Exploration Department, 100 Thames Valley Park Drive, RG6 1PT, \\ UK
}

\begin{abstract}
Turbidites deposited in confined mini-basins may demonstrate extremely complex stratigraphic architectures. We hypothesize that particulate organic matter preserved in turbidites will not be randomly distributed and may be used to assist the identification of architectural elements. An integrated sedimentological and palynological study was conducted on confined turbidites in the Peïra Cava sub-basin of the Eocene to Oligocene Grès d'Annot system, SE France; this provides a natural laboratory, where certainty in the stratigraphy allows confidence in sampling of sub-environments. Elements reflect deposits from high and low density flows including: thin-beds that onlap the basin margin and heterolithics spread across the basin; base of slope megabeds; and thick-beds that have a proximal to distal expression from south to north across the basin. One hundred samples were collected from logged sections across the basin, with $10 \mathrm{~g}$ of mudstone per sample being processed for a count of three hundred pieces of organic matter. Both allochthonous terrestrial and relatively autochthonous marine matter were recovered, with results showing a progressive fining of material from proximal to distal areas. Base of slope megabeds and proximal ponded thick beds are dominated by dense humic matter, medial areas become dominated by light plant material, and distal samples are dominated by amorphous matter, interpreted as a result of density sorting of organic matter in turbidity currents. Exploratory ordination analysis and fuzzy cluster analysis were used to examine these results. Based on this study, we provide evidence of density fractionation of
\end{abstract}


organics in turbidity currents, which is implied to be a major control on the distribution of particles in deep-marine depositional systems. This allows a palynofacies classification scheme to be developed to recognise architectural elements, which may be applied to sub-surface samples to assist the characterization of deep-water mini-basin architecture, understanding of which is crucial for hydrocarbon exploration and development.

Keywords: deep-water, particulate organic matter, confined turbidites, outcrop analogue, reservoir architecture, Peïra Cava

\section{Introduction}

Intra-slope mini-basins host producing hydrocarbon fields and are exploration targets in areas such the Gulf of Mexico (Clemenceau et al., 2000; Salazar et al., 2014), West Africa (Pirmez et al., 2000), and SE Asia (Demyttenaere et al., 2000). Mini-basins are kilometres to tens of kilometres in length and their stratigraphic architecture is typically complex, with an evolution of basin fill and spill in a confined setting, which is difficult to constrain without high resolution data (Prather et al., 1998; Booth et al., 2003). Architectural elements, e.g. basin margin onlap vs basinal heterolithics, are difficult to distinguish in mini-basins (Bouma, 1997) and typically require extensive outcrop analogues to be identified (Kneller and McCaffrey, 1999; Sinclair and Cowie, 2003). Correct placement of hydrocarbon exploration and development wells in these complex systems is crucial (Demyttenaere et al., 2000; Pirmez et al., 2000; Moraes et al., 2004; Madof et al., 2009; Salazar et al., 2014). As such, any tool that may be used to enhance the understanding of the distribution of architectural elements must be seen as an advantage.

This study seeks to expand the understanding of the distribution of organic matter in deepwater settings by examining turbidites confined in mini-basins. Study aims are 1) document reservoir scale architectural elements of structurally confined, deep-marine mini-basins; 2) 
examine the type of particulate organic matter preserved in these turbidite systems; 3) develop a palynofacies classification scheme to assist in the interpretation of depositional subenvironments in deep-water mini-basins. The goal is to provide a classification scheme applicable to sub-surface projects, to aid exploration and characterisation of sub-surface deepmarine mini-basins, understanding of which is crucial for correct well planning and hydrocarbon field development.

Palynofacies is the study of acid-resistant, microscopic particulate organic matter recovered from sediments (Combaz, 1964), and is regularly used in interpretations of terrestrial and shallow marine environments (Batten, 1982; Tyson, 1995; Batten, 1996; Batten and Stead, 2005). As with siliciclastic particles, organic particles may be entrained by currents (Muller, 1959; Stanley, 1986), to be deposited in turbidites. In this study we hypothesize that their distribution will not be random, but reflect transport and the environment of deposition (McArthur et al., 2016), with Tinterri et al. (2016) noting the importance of organic matter in recognising reflected beds in confined basins.

In order to test this hypothesis we examined outcrops of the Grès d'Annot turbidite system, in the Alpes Maritime, SE France (Fig. 1). These classical deep-water outcrops provide the perfect setting to study confined mini-basins, with over 60 years of detailed work providing a rigorous stratigraphic framework (see Salles et al., 2014; Šimíček and Bábek, 2015; Tinterri et al., 2016 and references within). Specifically, the Peïra Cava sub-basin provides excellent exposures through a fully confined mini-basin (Fig. 1; Kneller and McCaffrey, 1999; Amy et al., 2000; Kneller and McCaffrey, 2003; Amy et al., 2004; Lee et al., 2004; Amy et al., 2007; Aas et al., 2010, 2014).

\section{Geological setting}


The Eocene to Oligocene Grès d'Annot Formation of SE France comprises a deep-marine succession, preserved in Alpine synclines (Fig. 1; Bouma and Coleman, 1985; Sinclair, 1997; Sztrákos and du Fornel, 2003; Joseph and Lomas, 2004). Deposition occurred in a series of north-south orientated sub-basins, with a source area to the south in the Corsica-Sardinia massif (Stanley and Mutti, 1968; Ivaldi, 1974; Elliott et al., 1985; Ravenne et al., 1987; Sinclair, 2000; Apps et al., 2004).

It is a sand-rich turbidite system deposited in a structurally confined setting, which had an irregular basin floor, and has a total thickness up to $1500 \mathrm{~m}$, although sedimentation was not spatio-temporally uniform across the region (Kneller and McCaffrey, 1999; McCaffrey and Kneller, 2001; Sinclair and Cowie, 2003; Apps et al., 2004; Callec, 2004; du Fornel et al., 2004; Euzen et al., 2004). The turbidites onlap the underlying Marnes Bleues Formation (Riche et al., 1987). Some of the mini-basins were filled to their spill points, e.g. the Annot to Grand Coyer to Chalufy succession (Sinclair, 1993; Sinclair, 2000; Joseph and Lomas, 2004), while others, such as Peïra Cava were not filled to spill (Amy et al., 2007). Likely bathyal water depths with low oxygen levels were estimated based upon the in-situ benthonic foraminifera (Sztrákos and du Fornel, 2003). Sedimentation ceased as result of continued Alpine thrusting, with sediments to the east being unconformably truncated by the Schistes à Blocs (Ford and Lickorish, 2004).

\subsection{The Peïra Cava outlier}

The erosional remnant of one mini-basin outcrops around the village of Peïra Cava (Fig. 2), where road cuts and steep Alpine hillsides present excellent sections, which can be correlated across the basin (Amy et al., 2000, 2007). The Grès d'Annot Formation onlaps the Marnes Bleues Formation, with a basal thin-bedded unit (equivalent to the Marnes Brunes of Stanbrook and Clark, 2004) before developing into dominantly thick-bedded sandstones and mudstones, 
interspersed with mass-transport deposits, in all totalling c.1200 m (Amy et al., 2007), representing c.3.3 Ma of deposition (Sztrákos and du Fornel, 2003).

\section{Methodology}

\subsection{Palynological processing}

The stratigraphic framework of Amy et al. (2007) provided the basis for one hundred samples to be collected to cover each architectural element of the mini-basin. Samples were selected from clean, fresh outcrop of the darkest horizons of mudstone. Preservation of organics in coarse sediments is typically poor, with fluids free to move in coarse sediments and oxidise organic matter (Paropkari et al., 1992). Samples were taken at regular (c.10 m) intervals in logged sections to assess both lateral and vertical (temporal) variation.

A standard processing technique was used to avoid any discrepancies induced by processing methods (Table 1). A minimum of three hundred counts of particulate organic matter were undertaken per slide, using a Leica DM2500 binocular biological microscope, with transmitted, differential interference contrast, and fluorescent light. The long axis length of the first forty equant opaque phytoclasts observed was recorded for each sample (Tyson and Follows, 2000), along with visual inspection of their degree of rounding and sphericity. The dominant morphological features of miospores and dinoflagellate cysts (e.g. ornamentation), level, and types of deterioration shown by material was observed. All slides, residues and samples are housed in the Marleni Marques Toigo Laboratory of Palynology at UFRGS, Porto Alegre, Brazil, with laboratory codes MP-P 10559 to 11939.

\subsection{Particulate organic matter categories}


Sixteen categories were defined based upon their transmitted and fluorescent light properties (Fig. 3), grouping particles with similar characteristics to represent the total particulate organic matter assemblage (Fig. 3). Categories are based upon our observations of the organic matter, but largely agree with the categories of Boulter and Riddick (1986), van der Zwan (1990), Whitaker et al. (1992), Tyson (1995), and McArthur et al. (2016). Fungal material, mostly represented by fungal spores, was not sub-divided (sensu Boulter and Riddick, 1986) and wellpreserved wood was grouped with parenchyma (sensu van der Zwan, 1990).

Particles can be separated into allochthonous terrestrial material inferred to have been transported a relatively long distance and marine debris (Fig. 3), which was likely transported, but relatively autochthonous. Groupings are sorted by their inferred density as documented by Muller (1959), Cross et al. (1966), Traverse and Ginsburg (1967), Chaloner and Muir (1968), Riley (1970), Davey (1971), Koreneva (1971), Davey and Rogers (1975), Batten (1982), Tyson (1984), Kohl (1985), Boulter and Riddick (1986), van der Zwan (1990), Whitaker et al. (1992), Tyson (1995), Hoorn (1997), Oboh-Ikuenobe et al. (1999), Beaudouin et al. (2004), Jäger and McLean (2008), and Baudin et al. (2010).

\subsection{Statistical analysis}

Multivariate statistical analysis of the palynofacies dataset was conducted with PAST3 software (Hammer et al., 2001). Principle Components Analysis (PCA) and Detrended Correspondence Analysis (DCA) were performed. C-means Fuzzy Cluster (FCM) analysis (Gary et al., 2009) was conducted with the Technical Alliance for Computational Stratigraphy (TACSworks) software FCM module.

DCA is a metric ordination technique, based upon reciprocal averaging of eigenvalues (Hill, 1973), which highlights variations in the ecology that have the most influence on the data. Eigenvalues are determined for each variable, relating to their variation along an axis, therefore 
presenting values for each axis in terms of its impact on ecological variation. The result is a cross-plot of the axes that exhibit the most variance. This visual representation allows clusters of related samples to be grouped and trends to be examined. DCA was chosen given its reputation with palynological datasets (Courtinat and David, 1984; Kovach and Batten, 1994; Jolley and Whitham, 2004).

PCA determines theoretical variables (components) that account for as much variance as possible in the dataset, in order to display linear variations and reduce the dataset to the two most important variables, which it then displayed for visual analysis. PCA is commonly applied to palynological datasets (Oboh-Ikuenobe, 1996; Thomas et al., 2015).

Fuzzy clustering is an investigative technique that enables the identification of samples with related configurations, which sub-divides datasets into a series of clusters (Zadeh, 1965). Fuzzy clusters have gradational relationships to one another, whereby each sample may belong to one or more cluster to a varying degree (membership) as opposed to hard clustering techniques such as DCA, where each sample is unequivocally grouped (Fig. 4). Although relatively new for palaeontological data analysis, FCM is ideal for analysing transitional datasets (Wakefield et al., 2001; Gary et al., 2009; Daly et al., 2011; Erbs-Hansen et al., 2011, 2012; Martin et al., 2013). Every data point (sample) has the potential to belong to multiple clusters, therefore permitting representation of samples that are gradational between two or more clusters (Fig. 4) (Gary et al., 2009). Clusters are defined by an iterative process, fully explained by Gary et al. (2009), with cluster centroid values being used to define the dominant components of each cluster (Table 2). Once the clusters are defined, the membership of each sample to each cluster is expressed from 0 to 1 , where 0 is no relation and 1 is the same. This output is best illustrated by histograms of each sample's relation to each cluster, which can then be used to examine sets of samples with similar properties. FCM allows detailed investigations of ecosystem heterogeneity, which is not apparent in hard clustering methods such as PCA. 


\section{Sedimentology}

The sedimentological framework for this study is based upon a wealth of studies conducted on the Peïra Cava outcrops (Bouma, 1962; Stanley et al., 1978; Amy et al., 2000, McCaffrey and Kneller, 2001; Kneller and McCaffrey, 2003; Amy et al., 2004, Lee et al., 2004; Amy et al., 2007). The stratigraphic framework used here is based on seven correlated logs by Amy et al. (2007) (Fig. 5 and 6). This allowed recognition of four key lithofacies associations, summarized in figure 7. Amy et al. (2007) also recognised mass-transport deposits; these were not taken into account in this study as they provide information regarding the remobilized material rather than the final environment of deposition.

\subsection{Architectural element A (Fig. 7A)}

Descriptions: Thin $(<10 \mathrm{~cm})$ to medium-bedded (max $20 \mathrm{~cm}$ ), very fine to medium grained, well-sorted sandstones, with significant mudstone caps, typically at least the thickness of the underlying sandstone. Basal surfaces tend to be sharp, and may display groove and flute casts. Beds are typically laminated, cross-laminated or rippled, and normally graded. Ripples usually show different orientations in comparison to sole casts. Beds are observed to thin rapidly towards basin margins, where they truncate against the Marnes Bleues; the angle of dip is less inclined than the underlying marls. Deformation is commonly observed. Bioturbation is prevalent in both mud- and sandstone.

Interpretations: Basin margin onlap turbidites. Laterally thinning and truncating thin-beds, with highly discordant palaeocurrents are interpreted as low density turbidity current deposits, onlapping or draping over older, tilted slope deposits. These features have previously been interpreted as the result of flows onlapping and reflecting against major basinal slope surfaces (Kneller and McCaffrey, 1999; McCaffrey and Kneller, 2001; Puigdefàbregas et al., 2004). 
Deformation is inferred to be a product of slumping resulting from deposition on a relatively high angle slope (Stanbrook and Clark, 2004). These deposits have been described on the margins of the Peïra Cava mini-basin (Amy et al., 2004), likely representing the marginal equivalent of the thicker turbidites.

\subsection{Architectural element B (Fig. 7B)}

Descriptions: 25 to $35 \mathrm{~m}$ thick-bedded, gravel to fine grained, poorly-sorted sandstones (Fig. 5 and 6), with meters thick mudstone caps, and basal and internal mud-clast concentrations. Basal contacts are typically sharp and irregular, potentially truncating older beds, and show scour structures e.g. megaflutes. Bed bases may be gravel to coarse, but beds fine-up to fine and are typically capped by a meter or more silt- to mudstone cap. Rare internal chaotic horizons up to $3.5 \mathrm{~m}$ thick comprise a clast to matrix supported, clast-rich intervals, bearing mudstone, sandstone, and marl clasts up to $1.5 \mathrm{~m}$ long, set in an argillaceous matrix. Discrete pebble or mud-clast intervals may exist within otherwise structureless, massive, bodies. Mudcaps may show laminations, irregular sandstone lenses and pipes and are rich in macroscopic organic debris. Beds are observed to thin rapidly over several hundred metres northwards (McCaffrey and Kneller, 2001). Bioturbation is commonly observed in the mud-cap and vertical burrows often extend into the underlying sandstone.

Interpretations: Base of slope megabeds. These huge, structureless sandstones are interpreted as discontinuous base of slope megabeds infilling erosional scours (McCaffrey and Kneller, 2001; Amy et al., 2007), and forming localized wedges along the confining slope (Amy et al., 2007). These massive beds are interpreted to represent single events, though amalgamations may be inferred from pebble or mud-clast horizons. The mud-clast rich horizons are debrites, interpreted as hybrid events (Patacci et al., 2014), genetically related to the subsequent turbidite deposit. Thick mudstone caps to these beds indicate that sediments were trapped in a closed 
basin. Sandstone lenses and pipes within the mud-caps are interpreted as sand injectites, originating from the underlying sandstone.

\subsection{Architectural element C (Fig. 7C)}

Descriptions: Up to $5 \mathrm{~m}$ thick beds of poorly-sorted, very-coarse to fine grained, sandstones, with abrupt grain size breaks (Fig. 5 and 6). Bed bases are typically sharp and flat, but may show sole casts, e.g. flutes and grooves, and rare erosive surfaces. Beds may display a range of structures, typically with a massive basal interval, grading normally through trough crossstratification, planar stratification, and ripple lamination; although beds may also show convolute lamination, dish structures, flames, pipes, and loading structures. Typically nonamalgamated, with silt- to mudstone caps up to $5 \mathrm{~m}$ thick (Fig. 6), which often show sandstone pipes and thin sandstones and siltstones. May exhibit basal or internal mud-clast rich intervals, which are typically clast-rich but supported by a sandstone matrix. Generally observed to thin and fine to the north (Amy et al. 2007), but to maintain continuous, tabular, sheet-like geometries over 10's of km's (Amy et al. 2000). Bioturbation is prevalent, particularly in mudstone caps.

Interpretations: Ponded sheet turbidites. These laterally persistent, thick, tabular, sandstone rich beds are interpreted as the products of high and low density turbidity currents ponding in confined mini-basins. The limited accommodation space resulted in deposition as sheets across the basin, rather than discrete lobes. The excellent lateral continuity of these beds enables their use as marker beds in correlations across the basin, with Amy et al. (2007) defining 18 marked beds $(\mathrm{Mu})$ to provide lateral and vertical stratigraphic control across the basin. Mud-clast trains and or grain size breaks are interpreted as amalgamation surfaces. Beds are generally capped by significant mudstone intervals, implying this was a fully confined basin (Amy et al., 2007). 
Dewatering and injection of sandstone bodies implies rapid deposition and subsequent fluid escape (Tinterri et al., 2016).

\subsection{Architectural element D (Fig. 7D)}

Descriptions: Thin-bedded $(<10 \mathrm{~cm})$, coarse to fine grained sandstones, grading into silt- to mudstone caps that may be $>1 \mathrm{~m}$ thick (Fig. 5), occurring in packages up to $50 \mathrm{~m}$ thick. Sandstones are often $<1 \mathrm{~cm}$, with sharp, flat bases, occasionally show planar lamination, but typically ripple lamination, which may be bi-directional and switching between planar to ripple to planar lamination is not uncommon, associated with sharp grain size breaks. Sole structures are rarely observed. Rarely, in southern sections coarse sandstones exhibit trough crossstratification and megaripple structures, immediately overlain by mudstone. Mudstone intervals also show internal variation, with variably laminated, fissile, dark grey, organic rich intervals with siltstone interbeds, and light grey-blue, massive, foraminifera rich, calcareous intervals, with conchoidal fracture. Bioturbation is variable, but often intensive and may homogenize structures.

Interpretations: Heterolithic sheets. This association of thin, structured sandstones and thicker mudstones are interpreted as the products of low density turbidity currents. Organic rich, often laminated mudstones that directly overlie sandstones are interpreted as the mud rich portion of turbidites. Subsequent massive, calcareous intervals are interpreted as hemipelagic sediments. Turbidite mudstones may be differentiated sedimentologically from hemipelagic mudstones (Stow and Shanmugam, 1980; Talling et al., 2007). Turbidites may show very-thin, silty laminations, and are dark grey in colour. Lighter coloured, calcareous hemipelagites overly the turbidite mudstones. That mudstones are typically thicker than sandstones implies full confinement of the basin, with turbidity currents not over-spilling into other basins, however the presence of anti-dune structures in the southern end of the basin implies bypass (McCaffrey 
and Kneller, 2001). Bi-directional ripple directions are interpreted to be the result of flow reflection against basin edges (Kneller and McCaffrey, 1999; Tinterri et al., 2016), with reflected flows being able to traverse the relatively small basin. These packages imply periods of relative starvation of sediment supply.

\subsection{Spatial distribution of lithofacies associations}

Of the recorded lithofacies, base of slope megabeds (element B) are only present in the lower $50 \mathrm{~m}$ of southern sections, as the onlap is not preserved in higher parts of the succession (McCaffrey and Kneller, 2001). The basin margin onlap facies (element A) is only observed in the lower portions of logged sections, primarily exposed on the eastern margin of the basin, where lateral pinch-out of beds is apparent. The majority of the basin-fill is represented by sheet-like, typically non-amalgamated sandstones and mudstones of lithofacies C and D (Amy et al., 2000).

Variation in the architectural elements can be observed in north-south transects of the basin (Fig. 5 and 6), leading to the interpretation of proximal to distal representations of the succession (Amy et al., 2000, 2007; Aas et al., 2010). Amy et al. (2007) provides a detailed analysis of the changes in the succession, which are summarized in figure 7. As such, ponded sheets (element C) can be sub-divided into proximal (C1) medial (C2) and distal (C3) expressions, and heterolithics sheets (element D) can be sub-divided into proximal (D1) medial (D2) and distal (D3) representations.

4.5.1 The lower $700 \mathrm{~m}$ of the southern sections (1 and 2) demonstrate the thickest sandstone beds (up to $35 \mathrm{~m}$ ) and coarsest grain size, with the majority of thick sandstone beds initiating as gravels (Fig. 5 and 6; Amy et al., 2007). Net- to-gross averages 90\% in this interval (Amy et al., 2007).These intervals also display the megabeds (element B), which are not present further north (Fig. 5). Ponded sheets (element C1) show the highest internal variation in 
southern sections, with higher levels of amalgamation and meter scale erosive surfaces. Mudstone rafts up to $1.5 \mathrm{~m}$ long occur in southern sections. Thin-bedded heterolithic units are relatively rare (Fig. 5 and 6) and display bypass structures (McCaffrey and Kneller, 2001). The marker bed pictured in figure 7 (Mu10) is $480 \mathrm{~cm}$ thick, displays one distinct amalgamation surface, with coarse sandstone packages separated by a $50 \mathrm{~cm}$ thick mud-clast rich interval, its mudstone cap is $60 \mathrm{~cm}$ thick.

Interpretation: Proximal slope influenced association. The thicknesses, coarse grain size and bypass structures in the southern outcrops are interpreted as the result of deposition near the base of slope, in the most proximal part of the preserved basin fill (Amy et al., 2007; Aas et al., 2010). Megabeds (element B) and thick-bedded sandstones (element C1) are interpreted to be the result of 1-2 flows per event (McCaffrey and Kneller, 2001; Amy et al., 2007). The very coarse grain size, amalgamations, relatively thin mudstone caps, and thin-bed bypass structures indicate significant bypass of material down-system.

4.5.2 The upper $200 \mathrm{~m}$ of sections 1 and 2 and medial sections (sections 3, 4, and 6) show laterally persistent thick sandstones (element C2) and thinner heterolithic units (element D2), without the megabeds seen in section 1 (Fig. 5 and 6). The general grain size, thickness and net-to-gross (50-70\%) of the package is reduced when compared to the southern sections (Amy et al., 2007). Thin-bedded intervals (element D2) become more common than southern sections (Fig. 5), but do not show significant traction or bypass structures. Mud-clast concentrations are less common, with clasts reaching a maximum of $30 \mathrm{~cm}$. By section 3 (4 km north of section 1), Mu10 is represented by a $250 \mathrm{~cm}$ thick interval, with a lower $75 \mathrm{~cm}$ of coarse to medium sandstone seperated from an upper $150 \mathrm{~cm}$ of coarse to fine sandstone by a $25 \mathrm{~cm}$ thick mudclast horizon; its mud-cap is $100 \mathrm{~cm}$ thick (Fig. 7). 
Interpretation: Proximal basin-plain. The relatively thick and continuous beds found in the upper portion of the southern sections and the whole of the medial sections are taken to represent deposition in the proximal basin-plain portion of the mini-basin (Amy et al., 2007). The transition from discontinuous megabeds and very-thick sandstones to thick sandstones in the upper parts of sections 1 and 2 are taken to represent a southwards shift in the depositional locus of the basin (Amy et al., 2007).

4.5.3 Northern sections (5 \& 7) display a dominance of thin-bedded intervals (element D3), with net-to-gross <60\% (Fig. 5; Amy et al., 2007). Marker sandstones beds (element C3) are thinner than in sections to the south (Fig. 5 and 6) but demonstrate thicker mud-caps, e.g. the mud-cap to MU 5 is $2 \mathrm{~m}$ thick in section 2, but is $5 \mathrm{~m}$ thick in section 7. Although bed bases are typically coarse, gravels are very scarce, and mud-clast intervals are very rare (Fig. 5), however slumping of beds is evident. Thin-beds typically display a variety of palaeocurrent directions, typically directed northwards at the base but generally southerly higher in beds (Amy et al., 2007). Mudstones typically contain a significant hemipelagic component and bioturbation is rare. Mu10 is represented by a $175 \mathrm{~cm}$ thick interval of coarse to fine-grained sandstone, with a sharp grain size break separating the lower $50 \mathrm{~cm}$ of coarse to medium sandstone from an upper $125 \mathrm{~cm}$ coarse to fine sandstone; its mud-cap is $150 \mathrm{~cm}$ thick (Fig. 7). Interpretation: Distal basin-plain. These deposits are interpreted as being deposited at the distal end of the basin (Amy et al., 2007), given the dominance of thin-bedded packages (element D3) and thick mud-caps to relatively thinner marker beds (element C3), with the mud rich component of turbidity currents predominantly ponding down-dip. The variation in palaeocurrents is interpreted as reflection of currents off the northern basin margin (Amy et al., 2007). This margin, although not preserved, is also postulated from the presence of slump units, interpreted to represent remobilisation of sediment deposited on a nearby slope. 


\section{Palynofacies of confined turbidites}

\subsection{Palynofacies}

Study of the organic matter of the four architectural elements and their sub-divisions (A, B, C1, C2, C3, D1, D2, D3) provides eight palynofacies associations (Fig. 8, 9 and 10). Data are presented primarily in their raw format to view stratigraphic trends (Fig. 8), but also in percentages as box and whisker charts, demonstrating the relative proportions of particulate organic matter for each architectural element (Fig. 9). Below we describe the palynofacies associated with each architectural element.

5.1.1. Element A, basin margin onlap (Fig. $10 \mathrm{H}$ ) samples display a moderately poorly-sorted palynofacies association (Fig. 8 and 9), dominated by amorphous organic matter (AOM). There is terrestrial material, mostly palynowafers and degraded wood, however marine clasts are dominant, and this element records the highest numbers of dinoflagellate cysts (Fig. 8 and 9). Dinocysts are relatively diverse, showing both chorate and proximate forms, with cysts such as Nematosphaeropsis sp. implying a relatively deep-water setting (Pross and Brinkhuis, 2005). Phytoclasts are typically sub-rounded and elongate, with maximum phytoclast size of $34 \mu \mathrm{m}$, and average of $8.1 \mu \mathrm{m}$.

5.1.2. Element B, base slope megabeds (Fig. 10A) exhibit very poorly-sorted assemblages, dominated by large fragments of degraded wood and palynowafers (Fig. 8 and 9), but are rich in AOM. Limited occurrences of opaque phytoclasts, well-preserved wood, miospores, and fungi make up the remainder of this palynofacies association. A wide diversity of miospores was observed, but dinocyst numbers are restricted. Spores may be large or small, but are typically spheroidal and evidence of reworked spores exists in the wide colour variation 
observed, from pale orange to dark brown. Phytoclasts are generally sub-angular and subelongate, reaching a maximum size of $1 \mathrm{~mm}$, but averaging $15 \mu \mathrm{m}$.

5.1.3. Element C1, proximal ponded sheets (Fig. 10B) show poorly-sorted assemblages dominated by degraded wood and palynowafers (Fig. 8 and 9). Miospores and dinocysts are more frequent when compared to the megabeds, but show low diversity, and less AOM (Fig. 8 and 9). Spores tend to be small $(<30 \mu \mathrm{m})$, simple, round specimens, while the dinocysts are predominantly simple proximate forms. Phytoclasts are sub-rounded, sub-elongate, generally smaller $(<50 \mu \mathrm{m})$ when compared to the megabeds, averaging $10.4 \mu \mathrm{m}$.

5.1.4. Element C2, medial ponded sheets (Fig. 10C) show moderately well-sorted assemblages dominated by palynowafers (Fig. 8 and 9), with less degraded wood and AOM recorded than in proximal areas (Fig. 8 and 9). Miospores and dinocysts are reduced in numbers and less diverse when compared to the proximal sections, but fungal spores are more abundant (Fig. 8 and 9). Phytoclasts are typically sub-angular to rounded, sub-elongate, up to $30 \mu \mathrm{m}$, and average $9 \mu \mathrm{m}$.

5.1.5. Element C3, distal ponded sheets (Fig. 10D) exhibit very poorly-sorted assemblages, dominated by palynowafers and AOM, with minor degraded wood and equant debris (Fig. 8 and 9). The amount of preserved wood and miospores are reduced when compared to medial sheets, but bladed opaque debris is more abundant (Fig. 8 and 9) and dinocysts show higher diversity. Phytoclasts are typically small $(<20 \mu \mathrm{m}$, average $7.8 \mu \mathrm{m})$, sub-angular, and elongate.

The trends from proximal to distal can be highlighted when examining individual marker beds (Fig. 8). For example, the marker bed MU5 demonstrates abundant degraded wood in proximal sections; dominance of palynowafers in medial sections, and AOM in distal sections (Fig. 8). Heterolithic sheets (element D) show varied palynofacies across the element as a whole, but 
differences are observed in their palynofacies when divided into proximal, medial and distal sections (Fig. 8 and 9).

5.1.6. Element D1, proximal heterolithic sheets (Fig. 10E) demonstrate very poorly-sorted assemblages (Fig. 9), with palynowafers, degraded wood, and AOM being most common. Palynomorphs are relatively rare, but most abundant for this sub-environment (Fig. 8 and 9). Miospores and dinocysts show moderate diversity in forms. Phytoclasts are typically subrounded and sub-spheroidal, ranging up to $31 \mu \mathrm{m}$ in size and averaging $9 \mu \mathrm{m}$.

5.1.7. Element D2, medial heterolithic sheets (Fig. 10F) are well-sorted, being dominated by palynowafers, with lesser counts of degraded wood (Fig. 8 and 9). AOM and palynomorphs and are very rare, with the lowest diversity of any sub-environment. Phytoclasts are typically sub-angular, sub-elongate, show a maximum size of $25 \mu \mathrm{m}$ and average $10 \mu \mathrm{m}$.

5.1.8. Element D3, distal heterolithic sheets (Fig. 10G) are moderately well-sorted, being dominated by AOM (Fig. 8 and 9). Palynowafers, degraded wood, and equant debris are all typically rare; palynomorphs are very rare, though more abundant and diverse than in the medial heterolithics (Fig. 8 and 9); only a few dinocysts were recorded and were exclusively simple proximate forms. Phytoclasts are typically rounded and spheroidal, up to $18 \mu \mathrm{m}$ long and averaging $7.5 \mu \mathrm{m}$.

\subsection{Statistical analysis}

Results show proximal to distal regions of the basin to have distinct organic signatures (Fig. 8, 9 and 10), indicating that variations in the observed particles may aid differentiation of architectural elements. The inherent variation in turbidity current competence (Kneller, 1995), particularly as flows passed from proximal to distal areas and experienced variation in confinement, leads to variation in both siliciclastic and organic particles within any one bed in 
a sub-environment. Therefore, statistical examination of the dataset is appropriate to test the variability.

5.2.1 DCA (Fig. 11) shows loosely constrained groupings, corresponding to proximal, medial and distal sections. The megabeds and most proximal thick-beds plot towards the top of the chart, whereas distal and onlap beds plot to the right. Medial beds cluster towards the bottom left, but also trend towards the centre. The primary axis exerts the principle control on the groupings (eigenvalue 0.22) and would appear to be a factor of marine influence on the samples. This is an empirical observation, given that samples with the highest proportion of marine material are grouped to the right side of the chart, while those with the least marine particles group to the left. Particle heterogeneity may be exerting the control on the second axis (eigenvalue 0.07), given that samples higher up the chart are the most poorly-sorted, whereas those at the bottom represent the best sorted.

5.2.2 PCA (Fig. 12) corroborates the finding of the DCA, showing proximal samples towards the top of the diagram, medial to the bottom left, and distal to the right. The biplot allows the controls on this distribution to be analysed, with degraded wood plotting towards the top, palynowafers are the main particle type in medial samples, and AOM is dominant in distal samples (Fig. 12). The primary axis is inferred to be a factor of marine influence and to be controlling the distribution (accounting for $74 \%$ of the variance). The secondary axis (accounting for $21 \%$ of the variance) is probably a factor of sorting, given the spread of samples.

5.2.3 C-means Fuzzy Cluster. Although able to distinguish proximal, medial and distal parts of the basin, multivariate analysis does not clearly distinguish between detailed elements. As such FCM analysis was performed on the dataset (Fig. 13). The fuzzy exponent was varied between 1.1 (hard clusters) and 3.0 (highly gradational, soft clusters) in order to understand the data 
structure and constrain the FCM parameters (Gary et al., 2009). The optimum number of clusters was defined by the degree of compaction and separation of the dataset (Gary et al., 2009). Five clusters were the optimum, using a fuzzy exponent value of 1.5 (Table 2); various runs were made, but with more clusters their integrity was lost, with too much similarity between clusters; use of fewer clusters was insufficient to describe the observed variation. The five clusters are named for their primary and secondary representative matter type (Table 2; Fig. 13).

Cluster 1 is dominated by palynowafers (cluster centroid value 64.8), with minor representation from degraded wood (cluster centroid value 16.5). Cluster 2 is dominated by degraded wood (cluster centroid value 35.2) and palynowafers (cluster centroid value 35.0). Cluster 3 is represented by AOM (cluster centroid value 40.6), with palynowafers (cluster centroid value 25.5). Cluster 4 is represented by palynowafers (cluster centroid value 48.0), with minor AOM (cluster centroid value 20.6). Cluster 5 is dominated by AOM (cluster centroid value 62.2).

FCM results corroborate the PCA biplot analysis, demonstrating the relative abundances of AOM, palynowafers, and degraded wood to be the main variables in the dataset (Fig. 13). However, FCM analysis allows a deeper investigation of the architectural elements, with separation of architectural elements based upon their cluster membership. Samples from the onlap (element A) are fully represented in clusters 3 and 5 (Fig. 13), being dominated by AOM. Megabed (element B) samples have an affinity with cluster 2 (Fig. 13), being poorly-sorted but rich in degraded wood. Proximal sheets (element C1) are also related to cluster 2 and to a lesser extent cluster 1 (Fig. 13). Proximal heterolithics (element D1) are dominated by cluster 2, but with minor membership of clusters 4 and 3 (Fig. 13) and, unlike the proximal sheets, heterolithic samples show no membership in cluster 1 . The transition to medial elements is clearly marked by a shift towards dominance of cluster 1 (Fig. 13), with sheets (element C2) showing minor representation in clusters 4 and 2, while heterolithics (element D2) are also 
represented in cluster 4 (Fig. 13). Distal samples show a shift towards cluster 4 for sheets (element C3) and 5 for heterolithics (element D3) (Fig. 13). Although onlap samples are similar to distal heterolithics (Fig. 13), onlap samples have no representation in clusters 1 and 2.

\section{Discussion}

6.1 Distribution of particulate organic matter in confined turbidite systems

Despite the deep-marine setting of the Peïra Cava mini-basin, the abundance of terrestrially derived organic matter implies significant transport of material to the deep-water setting. Previous models have identified the system as being fed from fluvio-deltaic systems on the Corsica-Sardinia Massif (Hilton, 1995; Joseph et al., 2000; Sinclair, 2000; Joseph and Lomas, 2004), which is consistent with our palynological investigation. It is recognised that marine currents may transport organic matter (Muller, 1959; Cross et al., 1966; Tyson, 1984; Boulter and Riddick, 1986; Stanley, 1986; Caratini, 1994; Tyson, 1995; Hoorn, 1997; Oboh-Ikuenobe and Yepes, 1997; Oboh-Ikuenobe et al., 1999; Beaudouin et al., 2004; Baudin et al., 2010; Schiøler et al., 2010; Biscara et al., 2011; Stetten et al., 2015), which accounts for the dominance of terrestrial material.

A number of factors may contribute to the delivery and preservation of organic matter in the marine environment (Zonneveld et al., 2010). These include: sea-surface conditions; water depth; source and supply of organic matter; climate; sediment type and accumulation rates; bottom water oxygenation; productivity; hydrodynamic sorting and winnowing owing to the varying degrees of energy within the deep-marine system; tectonic setting; and diagenesis (Muller, 1959; Cross et al., 1966; Traverse and Ginsburg, 1967; Groot and Groot, 1971; Koreneva, 1971; Tyson, 1987, 1995; Oboh-Ikuenobe and Yepes, 1997; Thomas et al., 2015). 
However, many of these factors are of limited importance in turbidity currents (Tyson, 1995) with currents, local vegetation, and oxygenation being the key factors in the supply of organic matter to turbidite systems (Caratini, 1994; Tyson, 1995; Jäger and McLean, 2008).

Given that all our samples were taken from turbidites, deposited at a broadly similar water depth, show an abundance of well-preserved matter, uniform sediment colour, and ubiquitous bioturbation (Phillips et al., 2011), but exhibit variations in the proportion of different types of organic matter, implies that oxygenation was not a major factor here. The studied turbidites are also considered to have experienced rapid burial, which aids the preservation of organic matter (Stanley, 1986). The local vegetation type and distribution has a control on the type and abundance of organic matter delivered to a marine basin (Koreneva, 1971; Tyson, 1995; ObohIkuenobe et al., 1999; Baudin et al., 2010). However, no significant stratigraphic and therefore temporal variations were observed in the particulate organic matter, implying stable hinterland vegetation.

This leaves currents as the main factor of control, given the material has been actively transported by turbidity currents. It is known that organic matter may be transported hundreds of kilometres by turbidity currents (Meiburg and Kneller, 2010), and that siliciclastic particles become differentially sorted during transport, with decelerating flows losing the competence to transport progressively smaller grains (Lowe, 1982; Postma et al., 1988; Mutti, 1992). Density sorting during transport would appear most likely to be the primary control on the distribution of organic matter in turbidite systems, with numerous studies citing hydrodynamics as the most important factor responsible for the distribution of organic matter in marine environments (Muller, 1959; Cross et al., 1966; Traverse and Ginsburg, 1967; Groot and Groot, 1971; Koreneva, 1971; Tyson, 1984; Boulter and Riddick, 1986; van der Zwan, 1990; Whitaker et al., 1992; Caratini, 1994; Tyson, 1995; Tyson and Follows, 2000). 
Once entrained in a turbidity current, organic particles will act as sedimentary particles, with settling velocity largely controlled by particle size, density, shape, and texture (Muller, 1959; Cross et al., 1966; Traverse and Ginsburg, 1967). Therefore a hydraulic fractionation of organic matter in a turbidity current may occur, with smaller, lighter material having the greatest potential for transportation (Tyson and Follows, 2000). Given that organic particles are generally less dense than siliciclastic particles, organic matter will be concentrated in the upper, mud rich portion of turbidites, which represent the low density fraction of flows; concentration of organic matter this is also seen in tops of reflected bores (Tinterri et al., 2016).

\subsection{Palynofacies classification of deep-marine confined mini-basin architectural elements}

The application of the palynofacies characteristics observed here allows the classification of architectural elements of the mini-basin (Table 3; Fig. 14). No sharp variations exist to separate the elements, with spatial variation in organic matter primarily dependant on the behaviour of turbidity currents as they passed down-stream or entered areas of greater confinement e.g. against the confining basin margin (Kneller, 1995).

The highest energy and most proximal, slope influenced samples contain the largest and densest fraction of the organic matter (Fig. 14). As flows passed to more distal areas of the basin the ability of those flows to carry dense material decreased, leading to concentrations first of lighter terrestrial material, in the proximal basin plain and subsequently, lighter marine matter in distal areas (Fig. 14). Although marine AOM is common is shallow waters (Caratini, 1994), where the turbidity currents may have originated (Sinclair, 2000; Joseph and Lomas, 2004), it is likely that significant amounts of the AOM were entrained by turbidity currents as they passed through the basin. Entrainment of ambient seawater into turbidity currents is a recognised phenomenon on seafloor gradients in excess of 0.5 degrees (Ellison and Turner, 
1959; Postma et al., 1988; Stacey and Bowen, 1988; Birman et al., 2009; Nakajima and Kneller, 2013) and provides the most obvious means of increasing the proportion of AOM.

Although sedimentologically similar, thin-beds of the basin margin onlap and distal heterolithics palynofacies signatures can be differentiated, particularly with the aid of FCM analysis (Fig. 13). Other factors such as the increased abundance and diversity of dinocysts in onlap sections when compared with basinal heterolithics, and the size and shape variation in phytoclasts, may be used to differentiate similar architectural elements (Table 3).

\subsection{Comparison with other studies}

The palynofacies associations described here are broadly similar to the upper slope channellevee example presented by McArthur et al. (2016), being either rich in terrestrial or marine matter or a combination (Fig. 14). However, there are significant differences in the proportions of organic matter, with the channel system presenting much higher proportions of the densest types of matter throughout. The slope channel architectural elements described by McArthur et al. (2016) present different depositional environments to the confined mini-basin described here, and whereas the channel-levee was point sourced, the Annot turbidites were fed by fluviodelatic systems (Joseph and Lomas, 2004).

The channel-levee system contains channel and channel proximal sediments almost exclusively containing dense, opaque equant matter, with decay in the density of organic matter moving away from channels, but still with a dominantly terrestrial signature. Not until the outer portion of the levees was significant marine organic matter recorded. This clearly differs to our example, where the densest fraction of the terrestrial matter is never well-represented and marine organic matter is a common constituent in most architectural elements (Fig. 14). 
These differences are likely due to the depositional setting of the different environments and it is inferred that the densest material was already largely dropped from flows before they entered the mini basin, which was surely fed by a channel system (Mutti and Normark, 1987; Reading and Richards, 1994; Joseph and Lomas, 2004). The result is a concentration of lighter organic fragments in relatively more distal deep-marine settings, as is typically the case with the siliciclastic fraction (Lowe, 1982; Postma et al., 1988; Mutti, 1992). The next step is to test this methodology in unconfined, basin floor submarine fans.

\subsection{Implications for petroleum systems in confined mini-basins}

The ability to determine the location in a basin from the palynofacies is clearly of interest to the petroleum geologist, when considering development plans for hydrocarbon fields in confined mini-basins. Any one sample may not clearly indicate a relationship with any one architectural element, particularly given the overlap between thick and thin-beds in similar environments, which may be explained as only the mudstone caps were sampled. Nevertheless, a series of samples over a short interval will provide a robust indication of the depositional environment, and may be used in conjunction with sedimentological criteria, or in sub-surface studies may be combined with geophysical and petrophysical methods to assist the interpretation. Therefore, confidence in determining the position in the basin is higher and more significant than differentiating whether a sample is from thick or thin-beds. Although confidence in interpretation of elements based upon palynofacies is moderate to high (Table 3), it is not the intention that this tool be used in isolation, but that it should be integrated with all available data for the best interpretation.

Although thick sandstone beds are still present in the distal areas of the basin (Fig. 4), vertical connectivity of these potential reservoir units is impaired by the thick mud-caps and intervening thin-bedded heterolithic packages. Whereas amalgamated megabeds and thick sandstones are 
likely to have good horizontal and vertical connectivity in proximal settings. That thin-bedded turbidite elements can also be differentiated provide another powerful insight to the distribution of potential reservoir elements in confined mini-basins. The presence of onlap related thin-beds implies that thicker sandstones, with greater reservoir potential may be present in basinal areas (Kneller and McCaffrey, 1999; Sinclair, 2000; Patacci et al., 2014; Tinterri et al., 2016). Thinbedded turbidites may also present viable targets for gas reservoirs and correct identification of thin-bedded reservoirs may lead to improved calculations of recoverable reserves of a hydrocarbon field.

\section{Conclusions}

An integrated lithofacies and palynofacies study of a deep-marine, confined turbidite system has been conducted from outcrops, which have a well-documented stratigraphic architecture. This allowed certainty in sample placement to develop a methodology for the identification of architectural elements, based on their palynofacies.

Seven sedimentary logs allowed the recognition of four key lithofacies associations, interpreted to represent architectural elements of the mini-basin fill. These comprised basin margin onlap; base of slope megabeds; ponded thick-bedded sheets and ponded heterolithics. These may be further divided based upon their proximal, medial, and distal position in the basin. Lithofacies associations provided the basis for sampling of turbidite mudstones at regular intervals. Samples were processed for palynofacies analysis and were found to contain sixteen types of particulate organic matter with terrestrial and marine origins.

The type and proportions of organic matter was observed to vary between the architectural elements, and in their proximal to distal expressions. Although some elements provide a similar signature, statistical analysis, particularly C-means Fuzzy Cluster analysis provides confidence in the palynofacies differentiation of the architectural elements. Proximal elements are 
typically dominated by dense terrestrial material, such as degraded wood; medial elements are dominated by light terrestrial material, particularly palynowafers; while distal elements are dominated by amorphous organic matter of marine origin. Further details such as the size of phytoclasts and diversity of palynomorphs may be used to provide further criteria for the palynological classification of architectural elements.

Distribution of particulate organic matter in turbidite systems is not random, with hydrodynamic sorting of organic particles leading to differential deposition and proportions of particles in different areas of deep-marine systems. This study provides evidence of density fractionation of organic matter in turbidity currents. This allows a palynofacies classification scheme to be developed to assist the recognition of architectural elements in deep-marine minibasins. This tool may now be applied to sub-surface samples in conjunction with traditional datasets to improve interpretations of reservoir architecture.

\section{Acknowledgements}

We thank BG Brasil for financial support for this project and permission to publish. BG Group is a wholly owned subsidiary of Royal Dutch Shell. McArthur is grateful to the Coordenação de Aperfeiçoamento de Pessoal de Nível Superior (CAPES) for the scholarship 049/2012. The Agência Nacional do Petróleo (ANP) are thanked for supporting this project. Massimo Zecchin is thanked for handling this paper and Roberto Tinterri is thanked for his constructive review, in addition to an anonymous reviewer.

\section{References cited}

Aas, T.E., Basani, R., Howell, J., Hansen, E., 2014. Forward modelling as a method for predicting the distribution of deep-marine sands: an example from the Peïra Cava Subbasin. Geol. Soc. London, Spec. Publ. 387, 247-269. doi:10.1144/SP387.9

Aas, T.E., Howell, J.A., Janocko, M., Midtkandal, I., 2010. Re-created Early Oligocene seabed bathymetry and process-based simulations of the Peïra Cava turbidite system. J. Geol. Soc. 167, 857-875. doi:10.1144/0016-76492009-005

Amy, L., Kneller, B., McCaffrey, W., 2000. Evaluating the links between turbidite characteristics and gross system architecture: upscaling insights from the turbidite sheet system of Peira Cava, SE France. Deep. Reserv. world Houston, SEPM, Gulf Coast Sect. 1-15. 
Amy, L.A., McCaffrey, W.D., Kneller, B.C., 2004. The influence of a lateral basin-slope on the depositional patterns of natural and experimental turbidity currents. Geol. Soc. London, Spec. Publ. 221, 311-330. doi:10.1144/GSL.SP.2004.221.01.17

Amy, L.A., Kneller, B.C., McCaffrey, W.D., 2007. Facies architecture of the Gres de Peira Cava, SE France: landward stacking patterns in ponded turbiditic basins. J. Geol. Soc. London. 164, 143-162. doi:10.1144/0016-76492005-019

Apps, G., Peel, F., Elliott, T., 2004. The structural setting and palaeogeographical evolution of the Grès d'Annot Basin. Geol. Soc. London, Spec. Publ. 221, 65-96. doi:10.1144/GSL.SP.2004.221.01.05

Batten, D.J., 1982. Palynofacies, palaeoenvironments and petroleum. J. Micropalaeontology 1, 107-114. doi:10.1144/jm.1.1.107

Batten, D.J., 1996. Palynofacies and palaeoenvironmental interpretation, in: Jansonius, J.A.N., McGregor, D.C. (Eds.), Palynology: Principles and Applications, Vol 3. American Association of Stratigraphic Palynologists Foundation, Dallas, pp. 10111064.

Batten, D., Stead, D., 2005. Palynofacies analysis and its stratigraphic application. Appl. Stratigr. 203-226.

Baudin, F., Disnar, J.-R., Martinez, P., Dennielou, B., 2010. Distribution of the organic matter in the channel-levees systems of the Congo mud-rich deep-sea fan (West Africa). Implication for deep offshore petroleum source rocks and global carbon cycle. Mar. Pet. Geol. 27, 995-1010. doi:10.1016/j.marpetgeo.2010.02.006

Beaudouin, C., Dennielou, B., Melki, T., Guichard, F., Kallel, N., Berné, S., Huchon, A., 2004. The Late-Quaternary climatic signal recorded in a deep-sea turbiditic levee (Rhône Neofan, Gulf of Lions, NW Mediterranean): palynological constraints. Sediment. Geol. 172, 85-97. doi:10.1016/j.sedgeo.2004.07.008

Birman, V.K., Meiburg, E., Kneller, B., 2009. The shape of submarine levees: exponential or power law? J. Fluid Mech. 619, 367-376.

Biscara, L., Mulder, T., Martinez, P., Baudin, F., Etcheber, H., Jouanneau, J.-M., Garlan, T., 2011. Transport of terrestrial organic matter in the Ogooué deep sea turbidite system (Gabon). Mar. Pet. Geol. 28, 1061-1072. doi:10.1016/j.marpetgeo.2010.12.002

Booth, J.R., Dean, M.C., DuVernay, A.E., Styzen, M.J., 2003. Paleo-bathymetric controls on the stratigraphic architecture and reservoir development of confined fans in the Auger Basin: central Gulf of Mexico slope. Mar. Pet. Geol. 20, 563-586. doi:10.1016/j.marpetgeo.2003.03.008

Boulter, M., Riddick, A., 1986. Classification and analysis of palynodebris from the Palaeocene sediments of the Forties Field. Sedimentology 33, 871-886.

Bouma, A., 1962. Sedimentology of some flysch deposits: a graphic approach to facies interpretation. Elsevier, New York.

Bouma, A.H., 1997. Comparison of Fine-Grained, Mud-Rich and Coarse-Grained, Sand-Rich Submarine Fans for Exploration-Development Purposes. Gulf Coast Assoc. Geol. Soc. Trans. 47, 59-64.

Bouma, A., Coleman, J., 1985. Peira-Cava Turbidite System, France, in: Bouma, A., Normark, W., Barnes, N. (Eds.), Submarine Fans and Related Turbidite Systems SE - 
32, Frontiers in Sedimentary Geology. Springer New York, pp. 217-222. doi:10.1007/978-1-4612-5114-9_32

BRGM 2001a. Carte geologique de la St. Martin Vesubie au 1:50 000 vectorisées. Bureau de Recherches Geologiques et Minieres, Service Geologique National, Orleans.

BRGM 2001b. Carte geologique Menton - Nice au 1:50 000 vectorisées. Bureau de Recherches Geologiques et Minieres, Service Geologique National, Orleans.

Callec, Y., 2004. The turbidite fill of the Annot sub-basin (SE France): a sequencestratigraphy approach. Geol. Soc. London, Spec. Publ. 221, 111-135. doi:10.1144/GSL.SP.2004.221.01.07

Caratini, C., 1994. Palynofacies of some recent marine sediments: the role of transportation, in: Traverse, A. (Ed.), Sedimentation of Organic Particles. Cambridge University Press, Cambridge, pp. 129-139.

Chaloner, W.G., Muir, M., 1968. Spores and floras, in: Murchison, D., Westoll, T.S. (Eds.), Coal and Coal-Bearing Strata. Elsevier, New York, pp. 127-146.

Clemenceau, G.R., Colbert, J., Edens, D., 2000. Production results from levee-overbank turbidite sands at Ram/Powell field, deepwater Gulf of Mexico, in: Deep-Water Reservoirs of the World, GCSSEPM Foundation 20th Annual Research Conference. pp. 241-251.

Combaz, A., 1964. Les palynofaciès. Rev. Micropaléontologie 7, 205-213.

Courtinat, B., David, B., 1984. Analyse multivariee de trois populations de Corollina du Jurassique marocain. Rev. Palaeobot. Palynol. 41, 39-50.

Cross, A., Thompson, G., Zaitzeff, J., 1966. Source and distribution of palynomorphs in bottom sediments, southern part of Gulf of California. Mar. Geol. 4, 467-524.

Daly, R.J., Jolley, D.W., Spicer, R.A., Ahlberg, A., 2011. A palynological study of an extinct arctic ecosystem from the Palaeocene of Northern Alaska. Rev. Palaeobot. Palynol. 166, $107-116$.

Davey, R.J., 1971. Palynology and palaeo-environmental studies, with special reference to the continental-shelf sediments of South Africa, in: Farinacci, A. (Ed.), Proceedings of the Second Planktonic Conference, Roma. pp. 331-347.

Davey, R.J., Rogers, J., 1975. Palynomorph distribution in Recent offshore sediments along two traverses off South West Africa. Mar. Geol. 18, 213-225.

Demyttenaere, R., Tromp, J.P., Ibrahim, A., Allman-Ward, P., Meckel, T., 2000. Brunei Deep Water Exploration: From Sea Floor Images and Shallow Seismic Analogues to Depositional Models in a Slope Turbidite Setting, in: Deep-Water Reservoirs of the World: 20th Annual. SEPM, pp. 304-317. doi:10.5724/gcs.00.15.0304

du Fornel, E., Joseph, P., Desaubliaux, G., Eschard, R., Guillocheau, F., Lerat, O., Muller, C., Ravenne, C., Sztrakos, K., 2004. The southern Gres d'Annot outcrops (French Alps): an attempt at regional correlation. Geol. Soc. London, Spec. Publ. 221, 137-160. doi:10.1144/GSL.SP.2004.221.01.08

Ellison, T.H., Turner, J.S., 1959. Turbulent entrainment in stratified flows. J. Fluid Mech. 6, 423-448.

Erbs-Hansen, D.R., Knudsen, K.L., Gary, A.C., Gyllencreutz, R., Jansen, E., 2012. Holocene 
climatic development in Skagerrak, eastern North Atlantic: Foraminiferal and stable isotopic evidence. The Holocene 22, 301-312.

Erbs-Hansen, D.R., Knudsen, K.L., Gary, A.C., Jansen, E., Gyllencreutz, R., Scao, V., Lambeck, K., 2011. Late Younger Dryas and early Holocene palaeoenvironments in the Skagerrak, eastern North Atlantic: a multiproxy study. Boreas 40, 660-680.

Euzen, T., Joseph, P., du Fornel, E., Lesur, S., Granjeon, D., Guillocheau, F., 2004. Threedimensional stratigraphic modelling of the Gres d'Annot system, Eocene-Oligocene, SE France. Geol. Soc. London, Spec. Publ. 221, 161-180. doi:10.1144/GSL.SP.2004.221.01.09

Ford, M., Lickorish, W.H., 2004. Foreland basin evolution around the western Alpine Arc. Geol. Soc. London, Spec. Publ. 221, 39-63. doi:10.1144/GSL.SP.2004.221.01.04

Gary, A.C., Wakefield, M.I., Johnson, G.W., Ekart, D.D., 2009. Application of Fuzzy CMeans Clustering to Paleoenvironmental Analysis, in: Geologic Problem Solving with Microfossils. SEPM Society for Sedimentary Geology, pp. 9-20. doi:10.2110/sepmsp.093.009

Groot, J., Groot, C.R., 1971. Horizontal and verticle distribution of pollen and spores in Quaternary sequences, in: Funnel, B.M., Reidel, W.R. (Eds.), The Micropalaeontology of Oceans. Cambridge University Press, Cambridge, pp. 493-504.

Hammer, Ø., Harper, D.A.T., Ryan, P.D., 2001. PAST: Paleontological Statistics Software Package for education and data analysis. Palaeontolia Electronica 4.

Hill, M.O., 1973. Reciprocal Averaging: An Eigenvector Method of Ordination. J. Ecol. 61, 237-249. doi:10.2307/2258931

Hilton, V.C., 1995. Sandstone architecture and facies from the Annot Basin of the Tertiary SW Alpine Foreland Basin, SE France, in: Pickering, K.T., Hiscott, R.N., Kenyon, N.H., Ricci Lucchi, F., Smith, R.D.A. (Eds.), Atlas of Deep Water Environments SE - 33. Springer Netherlands, pp. 227-235. doi:10.1007/978-94-011-1234-5_33

Hoorn, C., 1997. Palynology of the Pleistocene glacial/interglacial cycles of the amazon fan (Holes 940A, 944A and 946A). Proc. Ocean Drill. Program, Sci. Results 155, 397-409.

Ivaldi, J.P., 1974. Origine du matériel détritique des séries Grès d’Annot d'après les données de la thermoluminescence (TLN et TLA). Géologie Alp. 50, 75-98.

Jäger, H., McLean, D., 2008. Palynofacies and spore assemblage variations of upper Viséan (Mississippian) strata across the southern North Sea. Rev. Palaeobot. Palynol. 148, 136153. doi:10.1016/j.revpalbo.2007.04.005

Jolley, D., Whitham, A., 2004. A stratigraphical and palaeoenvironmental analysis of the subbasaltic Palaeogene sediments of East Greenland. Pet. Geosci. 10, 53-60.

Joseph, P., Babonneau, N., Bourgeois, A., Cotteret, G., Eschard, R., Garin, B., de Souza, O., Granjeon, D., Guillocheau, F., Lerat, O., others, 2000. The Annot Sandstone outcrops (French Alps): architecture description as input for quantification and 3D reservoir modeling, in: P. Weimer, RM Slatt, J. Coleman, NC Rosen, H. Nelson, AH Bouma, MJ Styzen, and DT Lawrence, Deep-Water Reservoirs of the World: Gulf Coast Section SEPM Foundation 20th Annual Research Conference, SEPM CD Special Publication. pp. 422-449.

Joseph, P., Lomas, S.A., 2004. Deep-water sedimentation in the Alpine Foreland Basin of SE 
France: New perspectives on the Grès d'Annot and related systems—an introduction. Geol. Soc. London, Spec. Publ. 221, 1-16. doi:10.1144/GSL.SP.2004.221.01.01

Kneller, B., 1995. Beyond the turbidite paradigm: physical models for deposition of turbidites and their implications for reservoir prediction. Geol. Soc. London, Spec. Publ. 94, 3149. doi:10.1144/GSL.SP.1995.094.01.04

Kneller, B., McCaffrey, W., 1999. Depositional effects of flow nonuniformity and stratification within turbidity currents approaching a bounding slope; deflection, reflection, and facies variation. J. Sediment. Res. 69, 980-991. doi:10.2110/jsr.69.980

Kneller, B.C., McCaffrey, W.D., 2003. The interpretation of vertical sequences in turbidite beds: the influence of longitudinal flow structure. J. Sediment. Res. 73, 706-713.

Kohl, B., 1985. Biostratigraphy and Sedimentation Rates of the Mississippi Fan, in: Bouma, A., Normark, W., Barnes, N. (Eds.), Submarine Fans and Related Turbidite Systems SE39, Frontiers in Sedimentary Geology. Springer New York, pp. 267-273. doi:10.1007/978-1-4612-5114-9_39

Koreneva, E.V., 1971. Spore and pollen in Mediterranean bottom sediments, in: Funnel, B.M., Reidel, W.R. (Eds.), The Micropalaeontology of Oceans. Cambridge University Press, Cambridge, pp. 361-371.

Kovach, W.L., Batten, D.J., 1994. Association of palynomorphs and palynodebris with depositional environments: quantative approaches, in: Traverse, A. (Ed.), Sedimentation of Organic Particles. Cambridge University Press, New York, pp. 391-407.

Lee, S.E., Amy, L.A., Talling, P.J., 2004. The character and origin of thick base-of-slope sandstone units of the Peira Cava outlier, SE France. Geol. Soc. London, Spec. Publ. 221, 331-347. doi:10.1144/GSL.SP.2004.221.01.18

Lowe, D.R., 1982. Sediment gravity flows; II . Depositional models with special reference to the deposits of high-density turbidity currents. J. Sediment. Petrol. 52, 279-297.

Madof, A.S., Christie-Blick, N., Anders, M.H., 2009. Stratigraphic controls on a saltwithdrawal intraslope minibasin, north-central Green Canyon, Gulf of Mexico: Implications for misinterpreting sea level change. Am. Assoc. Pet. Geol. Bull. 93, 535561. doi:10.1306/12220808082

Martin, M.A., Wakefield, M., MacPhail, M.K., Pearce, T., Edwards, H.E., 2013. Sedimentology and stratigraphy of an intra-cratonic basin coal seam gas play: Walloon Subgroup of the Surat Basin, eastern Australia. Pet. Geosci. 19, 21-38.

McArthur, A.D., Kneller, B.C., Souza, P.A., Kuchle, J., 2016. Characterization of deepmarine channel-levee complex architecture with palynofacies: an outcrop example from the Rosario Formation, Baja California, Mexico. Mar. Pet. Geol. 73, 157-173. doi:10.1016/j.marpetgeo.2016.02.030

McCaffrey, W., Kneller, B., 2001. Process controls on the development of stratigraphic trap potential on the margins of confined turbidite systems and aids to reservoir evaluation. Am. Assoc. Pet. Geol. Bull. 85, 971-988.

Meiburg, E., Kneller, B., 2010. Turbidity currents and their deposits. Annu. Rev. Fluid Mech. 42, 135-156.

Moraes, M. A. S., Blaskovski, P.R., Joseph, P., 2004. The Gres d'Annot as an analogue for Brazilian Cretaceous sandstone reservoirs: comparing convergent to passive-margin 
confined turbidites. Geol. Soc. London, Spec. Publ. 221, 419-437.

doi:10.1144/GSL.SP.2004.221.01.23

Muller, J., 1959. Palynology of Recent Orinoco delta and shelf sediments: Reports of the Orinoco Shelf Expedition; Volume 5. Micropaleontology 5, 1-32.

Mutti, E., 1992. Turbidite sandstones. Agip, Istituto di geologia, Università di Parma.

Mutti, E., Normark, W.R., 1987. Comparing Examples of Modern and Ancient Turbidite Systems: Problems and Concepts, in: Leggett, J.K., Zuffa, G.G. (Eds.), Marine Clastic Sedimentology. Graham-Trotman, London, pp. 1-38.

Nakajima, T., Kneller, B.C., 2013. Quantitative analysis of the geometry of submarine external levees. Sedimentology 60, 877-910.

Oboh-Ikuenobe, F.E., 1996. Correlating palynofacies assemblages with sequence stratigraphy in Upper Cretaceous (Campanian) sedimentary rocks of the Book Cliffs, east-central Utah. Geol. Soc. Am. Bull. 108, 1275-1294. doi:10.1130/00167606(1996)108<1275:CPAWSS>2.3.CO;2

Oboh-Ikuenobe, F., Yepes, O., 1997. Palynofacies analysis of sediments from the Côte d'Ivoire-Ghana transform margin: Preliminary correlation with some regional events in the Equatorial Atlantic. Palaeogeogr. Palaeoclimatol. Palaeoecol. 129, 291-314.

Oboh-Ikuenobe, F.E., Hoffmeister, A.P., Chrisfield, R.A., 1999. Cyclical distribution of dispersed organic matter and dinocysts, ODP site 959 (early Oligocene-early Miocene, Côte d' Ivoire-Ghana transform margin). Palynology 23, 87-96.

Paropkari, A., Babu, C.P., Mascarenhas, A., 1992. A critical evaluation of depositional parameters controlling the variability of organic carbon in Arabian Sea sediments. Mar. Geol. 107, 213-226.

Patacci, M., Haughton, P.D.W., McCaffrey, W.D., 2014. Rheological Complexity In Sediment Gravity Flows Forced To Decelerate Against A Confining Slope, Braux, SE France. J. Sediment. Res. 84 , 270-277. doi:10.2110/jsr.2014.26

Phillips, C., McIlroy, D., Elliott, T., 2011. Ichnological characterization of Eocene/Oligocene turbidites from the Grès d'Annot Basin, French Alps, SE France. Palaeogeogr. Palaeoclimatol. Palaeoecol. 300, 67-83. doi:10.1016/j.palaeo.2010.12.011

Pirmez, C., Beaubouef, R.T., Friedmann, S.J., Mohrig, D.C., 2000. Equilibrium Profile and Baselevel in Submarine Channels: Examples from Late Pleistocene Systems and Implications for the Architecture of Deepwater Reservoirs, in: Deep-Water Reservoirs of the World: 20th Annual. SEPM, pp. 782-805. doi:10.5724/gcs.00.15.0782

Postma, G., Nemec, W., Kleinspehn, K.L., 1988. Large floating clasts in turbidites: a mechanism for their emplacement. Sediment. Geol. 58, 47-61. doi:10.1016/00370738(88)90005-X

Prather, B.E., Booth, J.R., Steffens, G.S., Craig, P.A., 1998. Classification, lithologic calibration, and stratigraphic succession of seismic facies of intraslope basins, deepwater Gulf of Mexico. Am. Assoc. Pet. Geol. Bull. 82, 701-728.

Pross, J., Brinkhuis, H., 2005. Organic-walled dinoflagellate cysts as paleoenvironmental indicators in the Paleogene; a synopsis of concepts. Paläontologische Zeitschrift 79, 5359. 
Puigdefàbregas, C., Gjelberg, J., Vaksdal, M., 2004. The Grès d’Annot in the Annot syncline: outer basin-margin onlap and associated soft-sediment deformation. Geol. Soc. London, Spec. Publ. 221, 367-388. doi:10.1144/GSL.SP.2004.221.01.20

Reading, H., Richards, M., 1994. Turbidite systems in deep-water basin margins classified by grain size and feeder system. Am. Assoc. Pet. Geol. Bull. 78, 792-822.

Riche, P., Tremolieres, P., Ravenne, C., Vially, R., 1987. Sédimentation et tectonique dans le bassin marin Eocène supérieur-Oligocène des Alpes du Sud. Oil Gas Sci. Technol. 42, 529-553.

Riley, G.A., 1970. Particulate organic matter in seawater. Adv. Mar. Biol. 8, 1-118.

Salazar, J.A., Knapp, J.H., Knapp, C.C., Pyles, D.R., 2014. Salt tectonics and Pliocene stratigraphic framework at MC-118, Gulf of Mexico: An integrated approach with application to deep-water confined structures in salt basins. Mar. Pet. Geol. 50, 51-67. doi:10.1016/j.marpetgeo.2013.11.003

Salles, L., Ford, M., Joseph, P., 2014. Characteristics of axially-sourced turbidite sedimentation on an active wedge-top basin (Annot Sandstone, SE France). Mar. Pet. Geol. 56, 305-323. doi:10.1016/j.marpetgeo.2014.01.020

Schiøler, P., Rogers, K., Sykes, R., Hollis, C.J., Ilg, B., Meadows, D., Roncaglia, L., Uruski, C., 2010. Palynofacies, organic geochemistry and depositional environment of the Tartan Formation (Late Paleocene), a potential source rock in the Great South Basin, New Zealand. Mar. Pet. Geol. 27, 351-369. doi:10.1016/j.marpetgeo.2009.09.006

Šimíček, D., Bábek, O., 2015. Spectral gamma-ray logging of the Grès d'Annot, SE France: An outcrop analogue to geophysical facies mapping and well-log correlation of sandrich turbidite reservoirs. Mar. Pet. Geol. 60, 1-17. doi:10.1016/j.marpetgeo.2014.10.010

Sinclair, H.D., 1993. High resolution stratigraphy and facies differentiation of the shallow marine Annot Sandstones, south-east France. Sedimentology 40, 955-978. doi:10.1111/j.1365-3091.1993.tb01371.x

Sinclair, H.D., 1997. Tectonostratigraphic model for underfilled peripheral foreland basins: An Alpine perspective. Geol. Soc. Am. Bull. 109, 324-346. doi:10.1130/00167606(1997)109<0324:TMFUPF>2.3.CO;2

Sinclair, H., 2000. Delta-fed turbidites infilling topographically complex basins: a new depositional model for the Annot Sandstones, SE France. J. Sediment. Res. 70, 504-519.

Sinclair, H.D., Cowie, P.A., 2003. Basin Floor Topography and the Scaling of Turbidites. J. Geol. 111, 277-299. doi:10.1086/373969

Stacey, M.W., Bowen, A.J., 1988. The vertical structure of density and turbidity currents: theory and observations. J. Geophys. Res. Ocean. 93, 3528-3542.

Stanbrook, D.A., Clark, J.D., 2004. The Marnes Brunes Inférieures in the Grand Coyer remnant: characteristics, structure and relationship to the Grès d'Annot. Geol. Soc. London, Spec. Publ. 221, 285-300. doi:10.1144/GSL.SP.2004.221.01.15

Stanley, D.J., 1986. Turbidity current transport of organic-rich sediments: Alpine and Mediterranean examples. Mar. Geol. 70, 85-101. doi:10.1016/0025-3227(86)90090-3

Stanley, D.J., Mutti, E., 1968. Sedimentological evidence for an emerged land mass in the Ligurian Sea during the Palaeogene. Nature 218, 32-36. 
Stanley, D.J., Palmer, H.D., Dill, R.F., 1978. Coarse sediment transport by mass flow and turbidity current processes and downslope transformations in Annot Sandstone canyonfan valley systems. Sediment. Submar. canyons, fans trenches 85-115.

Stetten, E., Baudin, F., Reyss, J.-L., Martinez, P., Charlier, K., Schnyder, J., Rabouille, C., Dennielou, B., Coston-Guarini, J., Pruski, A., 2015. Organic matter characterization and distribution in sediments of the terminal lobes of the Congo deep-sea fan: Evidence for the direct influence of the Congo River. Mar. Geol. 369, 182-195.

Stow, D.A. V, Shanmugam, G., 1980. Sequence of structures in fine-grained turbidites: comparison of recent deep-sea and ancient flysch sediments. Sediment. Geol. 25, 23-42.

Sztrákos, K., du Fornel, É., 2003. Stratigraphie, paléoécologie et foraminifères du paléogène des Alpes Maritimes et des Alpes de Haute-Provence (Sud-Est de la France). Rev. Micropaléontologie 46, 229-267. doi:10.1016/j.revmic.2003.09.003

Talling, P.J., Amy, L.A., Wynn, R.B., Blackbourn, G., Gibson, O., 2007. Evolution of turbidity currents deduced from extensive thin turbidites: Marnoso Arenacea Formation (Miocene), Italian Apennines. J. Sediment. Res. 77, 172-196.

Thomas, M.L., Pocknall, D.T., Warny, S., Bentley Sr, S.J., Droxler, A.W., Nittrouer, C.A., 2015. Assessing palaeobathymetry and sedimentation rates using palynomaceral analysis: a study of modern sediments from the Gulf of Papua, offshore Papua New Guinea. Palynology 39, 410-433.

Tinterri, R., Magalhaes, P.M., Tagliaferri, A., Cunha, R.S., 2016. Convolute laminations and load structures in turbidites as indicators of flow reflections and decelerations against bounding slopes. Examples from the Marnoso-arenacea Formation (northern Italy) and Annot Sandstones (south eastern France). Sediment. Geol. in press. doi:10.1016/j.sedgeo.2016.01.023

Traverse, A., Ginsburg, R., 1967. Pollen and associated microfossils in the marine surface sediments of the Great Bahama Bank. Rev. Palaeobot. Palynol. 3, 243-254.

Tyson, R. V., 1984. Palynofacies investigation of Callovian (Middle Jurassic) sediments from DSDP Site 534, Blake-Bahama Basin, Western Central Atlantic. Mar. Pet. Geol. 1, 313. doi:10.1016/0264-8172(84)90116-8

Tyson, R. V., 1987. The genesis and palynofacies characteristics of marine petroleum source rocks. Geol. Soc. London, Spec. Publ. 26, 47-67. doi:10.1144/GSL.SP.1987.026.01.03

Tyson, R. V., 1995. Sedimentary Organic Matter. Chapman \& Hall, London.

Tyson, R.V., Follows, B., 2000. Palynofacies prediction of distance from sediment source: a case study from the Upper Cretaceous of the Pyrenees. Geology 28, 569-571.

van der Zwan, C.J., 1990. Palynostratigraphy and Palynofacies Reconstruction of the Upper Jurassic to Lowermost Cretaceous of the. Rev. Palaeobot. Palynol. 62, 157-186.

Wakefield, M., Cook, R., Jackson, H., Thompson, P., 2001. Interpreting biostratigraphical data using fuzzy logic: the identification of regional mudstones within the Fleming Field, UK North Sea. J. Pet. Geol. 24, 417-440.

Whitaker, M.F., Giles, M.R., Cannon, S.J.C., 1992. Palynological review of the Brent Group, UK sector, north sea. Geol. Soc. London, Spec. Publ. 61, 169-202. doi:10.1144/GSL.SP.1992.061.01.10 
Zadeh, L.A., 1965. Fuzzy Sets. Inf. Control 8, 338-353.

Zonneveld, K.A.F., Versteegh, G.J.M., Kasten, S., Eglinton, T.I., Emeis, K.-C., Huguet, C., Koch, B.P., de Lange, G.J., De Leeuw, J.W., Middelburg, J.J., Mollenhauer, G., Prahl, F.G., Rethemeyer, J., Wakeham, S.G., 2010. Selective preservation of organic matter in marine environments; processes and impact on the sedimentary record. Biogeosciences 7, 483-511.

$10 \mathrm{~g}$ samples washed and disaggregated to fragments $1 \mathrm{~cm}^{3}$ $37 \%$ cold $\mathrm{HCl}$ for $2 \mathrm{hrs}$, dilute to neutral with distilled water $48 \%$ cold HF for $24 \mathrm{hrs}$, dilute to neutral with distilled water $37 \%$ cold $\mathrm{HCl}$ for $1 \mathrm{hr}$, dilute to neutral with distilled water $10 \mu \mathrm{m}$ sieve, palynofacies slide mounted with cellosize and entellan glue Table 1. Palynofacies slide preparation methods 


\begin{tabular}{|c|c|c|c|c|c|}
\hline Palynofacies type & $\begin{array}{r}\text { Cluster } 1 \\
\text { Equant } \\
\end{array}$ & $\begin{array}{r}\text { Cluster } 2 \\
\text { Degraded wood } \\
\end{array}$ & $\begin{array}{r}\text { Cluster } 3 \\
A O M\end{array}$ & $\begin{array}{r}\text { Cluster } 4 \\
\text { Wafers }\end{array}$ & $\begin{array}{r}\text { Cluster } 5 \\
A O M\end{array}$ \\
\hline Acritarchs & 0.0077 & 0.0115 & 0.0367 & 0.0415 & 0.0274 \\
\hline AOM & 12.1278 & 29.003 & 19.5099 & 8.5177 & 58.6559 \\
\hline Bisaccates & 0.0171 & 0.0282 & 0.092 & 0.073 & 0.0228 \\
\hline Blades & 4.2639 & 4.2735 & 2.1123 & 0.9517 & 2.7438 \\
\hline DSOM & 9.0291 & 3.1887 & 1.7648 & 0.8692 & 0.9937 \\
\hline Degraded wood & 15.318 & 17.9668 & 25.0505 & 16.6205 & 10.6824 \\
\hline Dinocysts & 0.1408 & 0.3824 & 1.2262 & 0.5702 & 0.4093 \\
\hline Equant debris & 50.1841 & 29.2913 & 8.7723 & 3.3807 & 13.6980 \\
\hline Freshwater algae & 0.0014 & 0.0172 & 0.0497 & 0.0283 & 0.0090 \\
\hline Fungai & 0.1118 & 0.7747 & 2.8221 & 2.0424 & 0.6434 \\
\hline Marine algae & 0.0704 & 0.0965 & 0.134 & 0.1268 & 0.1246 \\
\hline Miospores & 0.3637 & 1.0251 & 2.9319 & 1.5655 & 0.8091 \\
\hline Resin & 0.118 & 0.0731 & 0.0973 & 0.0701 & 0.0486 \\
\hline Palynowafers & 5.7974 & 11.682 & 32.751 & 62.5921 & 9.8173 \\
\hline Wood & 2.4482 & 2.1787 & 2.6344 & 2.5504 & 1.3106 \\
\hline Zoomorphs & 0.0001 & 0.0071 & 0.0147 & 0.0001 & 0.0042 \\
\hline
\end{tabular}




\begin{tabular}{|c|c|c|c|c|c|}
\hline $\begin{array}{l}\text { Irchitectural } \\
\text { element and } \\
\text { nain features } \\
\end{array}$ & Sorting & $\begin{array}{c}\text { Phytoclast size } \\
\text { and shape }\end{array}$ & $\begin{array}{c}\text { Ranges of } \\
\text { dominant } \\
\text { matter }\end{array}$ & $\begin{array}{l}\text { Median of matter and } \\
\text { (95\% confidence) }\end{array}$ & $\begin{array}{c}\text { Confidence } \\
\text { of ID }\end{array}$ \\
\hline $\begin{array}{l}\text { asin margin } \\
\text { lap (A); } \\
\text { OM rich. }\end{array}$ & $\begin{array}{l}\text { Poorly } \\
\text { sorted }\end{array}$ & $\begin{array}{l}\text { Max - } 34 \mu \mathrm{m}, \\
\text { Average - } 8.1 \mu \mathrm{m} \\
\text { Sub-rounded, } \\
\text { elongate }\end{array}$ & $\begin{array}{l}\text { AOM 42-60\% } \\
\text { Wafers } 12-30 \% \\
\text { Deg wood 10- } \\
20 \%\end{array}$ & $\begin{array}{l}\text { AOM 45\% (40-56\%) } \\
\text { Wafers } 20 \%(12-28 \%) \\
\text { Deg wood } 16 \%(9-18 \%)\end{array}$ & High \\
\hline $\begin{array}{l}\text { ase of slope } \\
\text { legabeds (B); } \\
\text { ggraded wood, } \\
\text { lynowafers. }\end{array}$ & $\begin{array}{l}\text { Very } \\
\text { poorly } \\
\text { sorted }\end{array}$ & $\begin{array}{l}\text { Max - } 1000 \mu \mathrm{m} \text {, } \\
\text { Average - } 15 \mu \mathrm{m} \\
\text { Sub-angular, sub- } \\
\text { elongate }\end{array}$ & $\begin{array}{l}\text { Deg wood 32- } \\
35 \% \\
\text { Wafers } 25-36 \% \\
\text { AOM } 18-22 \%\end{array}$ & $\begin{array}{l}\text { Deg wood 34\% (31- } \\
35 \%) \\
\text { Wafers 28\% (17-38\%) } \\
\text { AOM 19\% (16-23\%) }\end{array}$ & High \\
\hline $\begin{array}{l}\text { roximal sheets } \\
\text { 1); wafers } \\
\text { 1d degraded } \\
\text { ood. }\end{array}$ & $\begin{array}{l}\text { Poorly } \\
\text { sorted }\end{array}$ & $\begin{array}{l}\text { Max - } 50 \mu \mathrm{m}, \\
\text { Average }-10.4 \\
\mu \mathrm{m} \\
\text { Sub-rounded and } \\
\text { sub-elongate }\end{array}$ & $\begin{array}{l}\text { Wafers 33-49\% } \\
\text { Deg wood 26- } \\
36 \%\end{array}$ & $\begin{array}{l}\text { Wafers } 42 \%(35-45 \%) \\
\text { Deg wood } 31 \%(27- \\
34 \%)\end{array}$ & $\underline{\text { High }}$ \\
\hline $\begin{array}{l}\text { roximal } \\
\text { aterolithics } \\
\text { o1); wafers } \\
\text { 1d degraded } \\
\text { ood. }\end{array}$ & $\begin{array}{l}\text { Very } \\
\text { poorly } \\
\text { sorted }\end{array}$ & $\begin{array}{l}\text { Max - } 31 \mu \mathrm{m} \text {, } \\
\text { Average }-10 \mu \mathrm{m} \\
\text { Sub-angular and } \\
\text { sub-elongate }\end{array}$ & $\begin{array}{l}\text { Wafers } 33-40 \% \\
\text { Deg wood } 24- \\
35 \% \\
\text { AOM } 16-26 \%\end{array}$ & $\begin{array}{l}\text { Wafers 35\% (32-42\%) } \\
\text { Deg wood 29\% (22- } \\
35 \%) \\
\text { AOM 21\% (15-27\%) }\end{array}$ & Moderate \\
\hline $\begin{array}{l}\text { Iedial sheets } \\
\text { `2); wafers } \\
\text { sminated. }\end{array}$ & $\begin{array}{l}\text { M. well } \\
\text { sorted }\end{array}$ & $\begin{array}{l}\text { Max - } 30 \mu \mathrm{m} \text {, } \\
\text { Average }-9 \mu \mathrm{m} \\
\text { Sub-angular and } \\
\text { sub-elongate }\end{array}$ & $\begin{array}{l}\text { Wafers } 41-61 \% \\
\text { Deg wood 19- } \\
27 \% \\
\text { AOM } 10-20 \%\end{array}$ & $\begin{array}{l}\text { Wafers 52\% (43-60\%) } \\
\text { Deg wood 22\% (18- } \\
25 \%) \\
\text { AOM } 11 \%(8-17 \%)\end{array}$ & Moderate \\
\hline $\begin{array}{l}\text { Iedial } \\
\text { sterolithics } \\
\text { J2); wafers } \\
\text { ominated. }\end{array}$ & $\begin{array}{l}\text { Well } \\
\text { sorted }\end{array}$ & $\begin{array}{l}\text { Max - } 25 \mu \mathrm{m}, \\
\text { Average }-10 \mu \mathrm{m} \\
\text { Sub-angular and } \\
\text { sub-elongate }\end{array}$ & $\begin{array}{l}\text { Wafers } 39-72 \% \\
\text { Deg wood } 10- \\
22 \% \\
\text { AOM } 4-10 \%\end{array}$ & $\begin{array}{l}\text { Wafers } 65 \%(37-90) \\
\text { Deg wood } 17 \%(6-24 \%) \\
\text { AOM } 5 \%(1-10 \%)\end{array}$ & Moderate \\
\hline $\begin{array}{l}\text { istal sheets } \\
\text { ב3); wafers } \\
\text { ıd AOM. }\end{array}$ & $\begin{array}{l}\text { Very } \\
\text { poorly } \\
\text { sorted }\end{array}$ & $\begin{array}{l}\text { Max } 20 \mu \mathrm{m} \text {, } \\
\text { Average } 7.8 \mu \mathrm{m} \\
\text { Sub-angular and } \\
\text { elongate }\end{array}$ & $\begin{array}{l}\text { Wafers } 33-52 \% \\
\text { AOM } 19-38 \% \\
\text { Deg wood 12- } \\
16 \%\end{array}$ & $\begin{array}{l}\text { Wafers } 46 \%(38-51 \%) \\
\text { AOM } 28 \%(22-35 \%) \\
\text { Deg wood 14\% (13- } \\
15 \%)\end{array}$ & Moderate \\
\hline $\begin{array}{l}\text { istal } \\
\text { sterolithics } \\
\text { J3); AOM } \\
\text { ch }\end{array}$ & $\begin{array}{l}\text { M. well } \\
\text { sorted }\end{array}$ & $\begin{array}{l}\text { Max } 18 \mu \mathrm{m} \\
\text { Average } 7.5 \mu \mathrm{m} \\
\text { Rounded and } \\
\text { spheroid }\end{array}$ & $\begin{array}{l}\text { AOM 43-63\% } \\
\text { Wafers 11-19\% } \\
\text { Deg wood 9- } \\
\text { 14\% } \\
\text { Equant 5-14\% }\end{array}$ & $\begin{array}{l}\text { AOM 52\% (43-62\%) } \\
\text { Wafers } 17 \%(13-22 \%) \\
\text { Deg wood } 12 \%(9-14 \%) \\
\text { Equant } 10 \%(6-15 \%)\end{array}$ & $\underline{\text { High }}$ \\
\hline
\end{tabular}

\section{Figure captions}

Fig. 1. Structural map of SE France, exhibiting the main mini-basins of the Grès d'Annot system and highlighted area for the location of figure 2. From Joseph and Lomas (2004).

Fig. 2. Simplified geological map of the Peïra Cava outlier, illustrating the measured sections used to collect samples (after Amy et al., 2007). Developed from BRGM 1:50000 maps, 0947 (BRGM 2001a) and 0973 (BRGM 2001b). 
Fig. 3. Particulate organic matter encountered in this study, sorted by inferred buoyancy. Description based upon our observations and hydrodynamic properties based upon characteristics documented by previous workers (cf. McArthur et al., 2016). All scale bars $50 \mu \mathrm{m}$.

Fig. 4. Graphic representation of dataset division for "hard" or non-fuzzy clustering vs. mixed division afforded by fuzzy clustering. From Wakefield et al. (2001).

Fig. 5. Measured sections from the eastern extent of the Peïra Cava mini-basin, after Amy et al. (2007). Locations of the collected samples are indicated.

Fig. 6. Measured sections from the western extent of the Peïra Cava mini-basin, after Amy et al. (2007). Locations of the collected samples are indicated.

Fig. 7. Schematic spatial distribution of the lithofacies associations A-D of the Grès d'Annot Formation at Peira Cava, with examples of each depositional element and south to north variations in lithofacies $B$, interpreted as proximal, medial and distal variations of marker units. Hammer for scale is $35 \mathrm{~cm}$ long.

Fig. 8. Count data for each sample organized by architectural elements in stratigraphic order; Equant - equant opaque; DM - dark structureless organic matter; R - resin; Fun - fungi; FA Freshwater Algae; Z-zoomorphs; Dino - dinocysts; A - acritarchs; BS - bisaccate pollen; MA marine algae. Marker unit 5 (Mu5) is highlighted in the sheet samples.

Fig. 9. Box and whisker charts of the percentage of particulate organic matter recorded for each sample from the studied architectural elements; DSOM - dark structureless organic matter; Degrade - degraded wood; Wood - well preserved wood; FWA - freshwater algae; Dinocysts dinoflagellate cysts; Sacs - bisaccate pollen; MA - marine algae; AOM - amorphous organic matter. Boxes represent the 25th to 75th percentile, with notches indicating the $95 \%$ confidence interval of the median; whiskers represent the 25th percentile minus 1.5 times the range of the box and the 75th percentile plus 1.5 times the range of the box values (interquartile range); circles represent outliers.

Fig. 10. Palynofacies assemblages recorded in A) megabed B), proximal sheet C) medial sheet, D) distal sheet, E) proximal heterolithics, F) medial heterolithics, G) distal heterolithics, H) onlap architectural elements palynofacies. All to the same scale.

Fig. 11. Detrended correspondence analysis (DCA) cross-plot of the Peïra Cava dataset.

Fig. 12. Principle components (PCA) cross-plot of the Peïra Cava dataset. 
Fig. 13. Fuzzy-cluster (FCM) analysis plots of the Peïra Cava dataset. The membership of each sample is charted for each cluster, with average values for each architectural element shaded grey.

Fig. 14. Schematic illustration of the distribution of particulate organic matter in a confined minibasin. See figure 3 for guide to organic matter types.

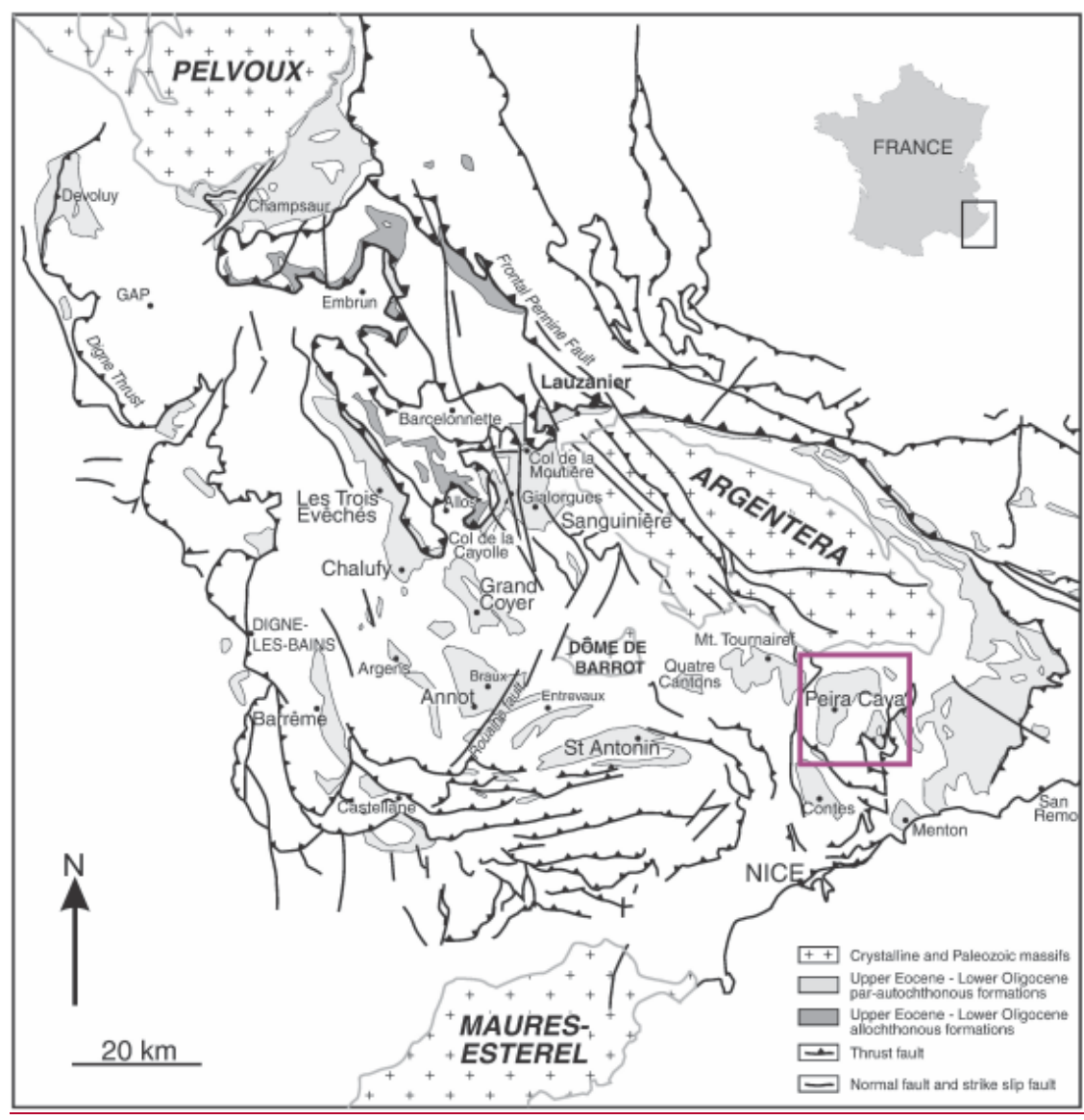




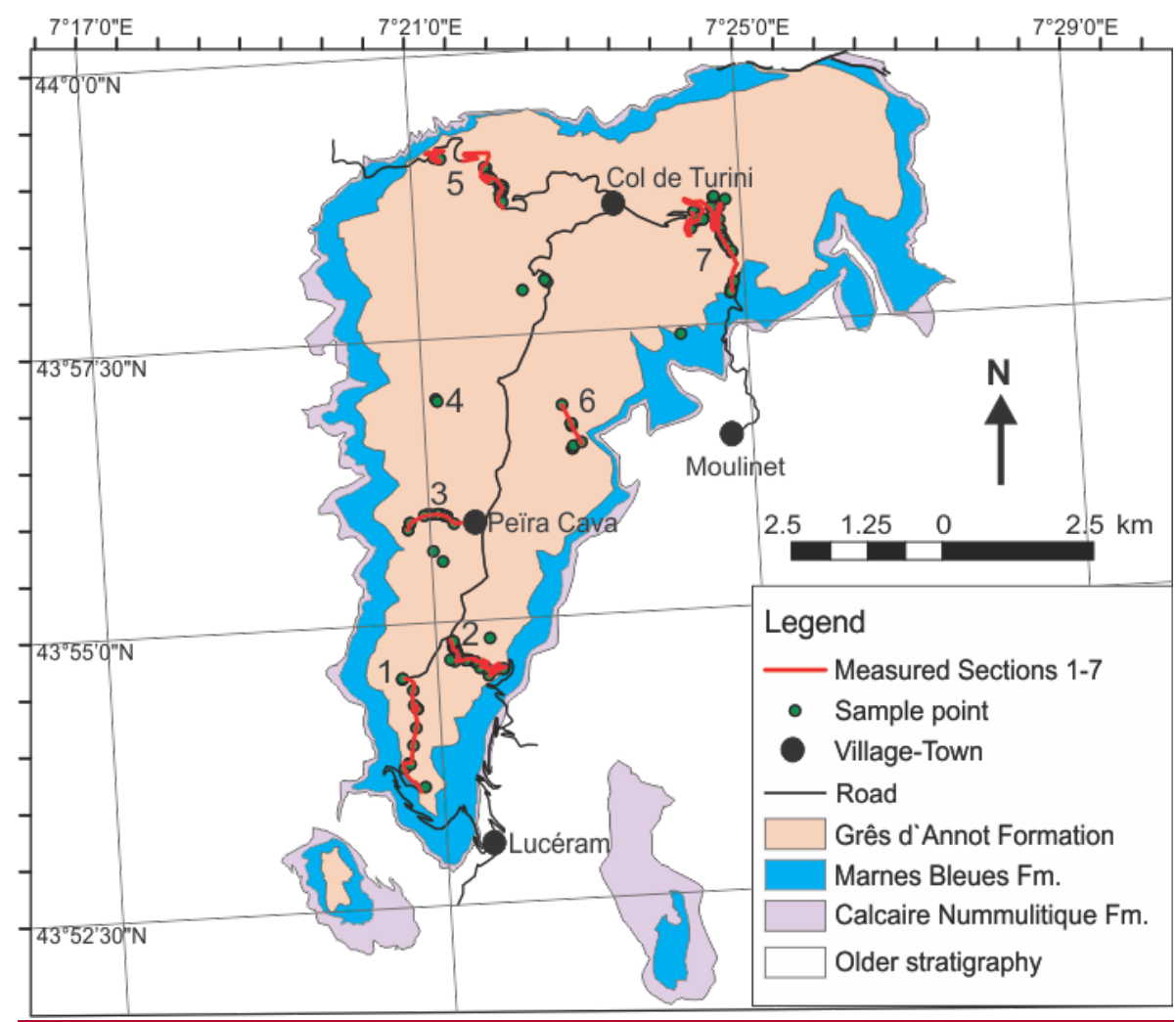




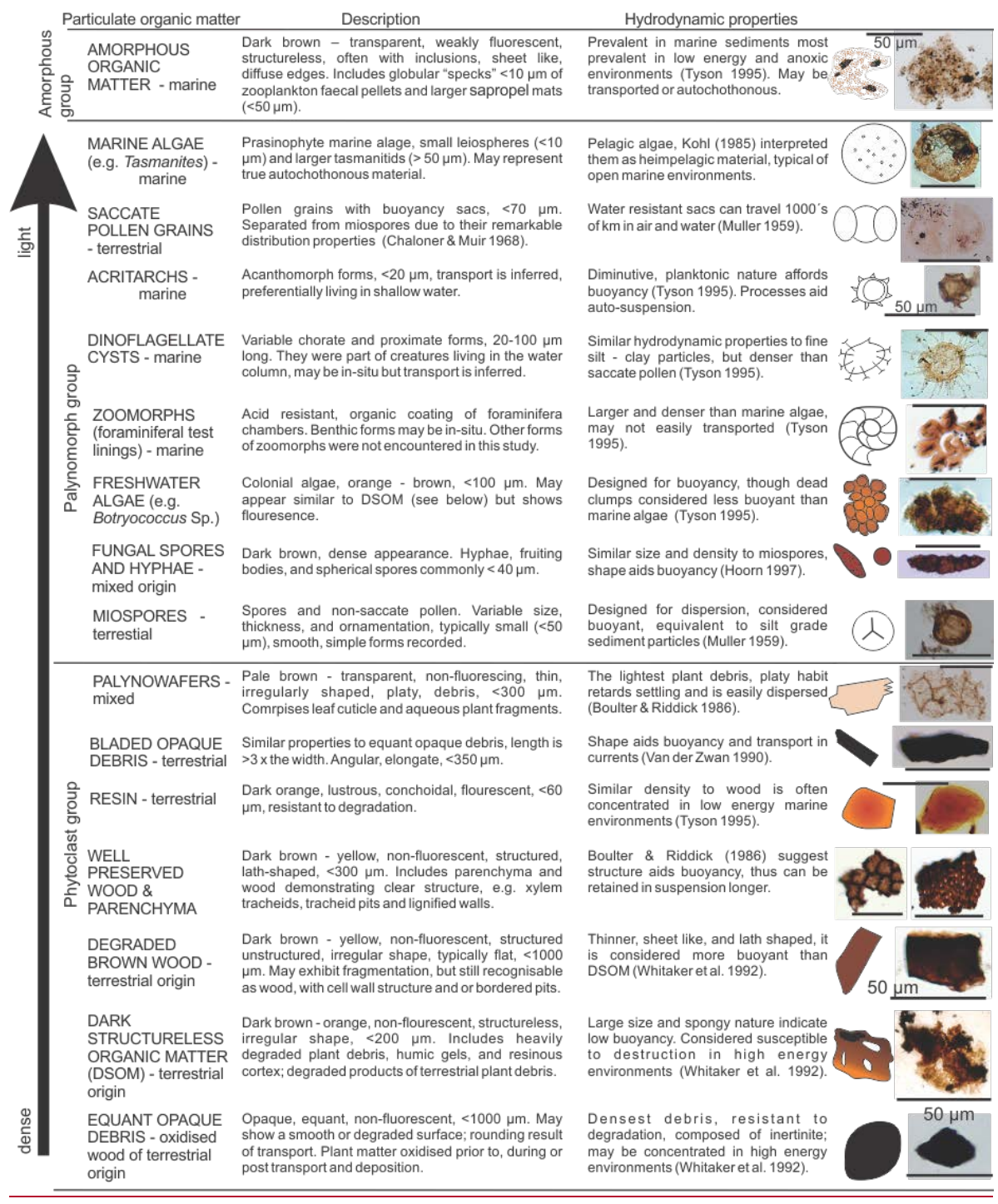


"Hard" clustering - e.g. DCA

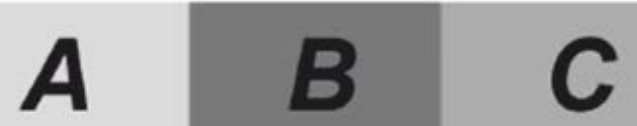

Fuzzy clustering - e.g. FCM

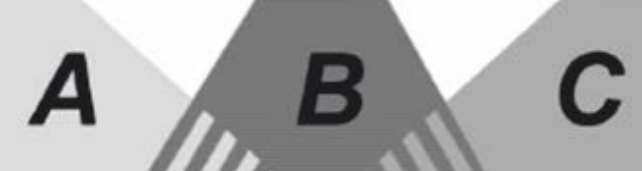




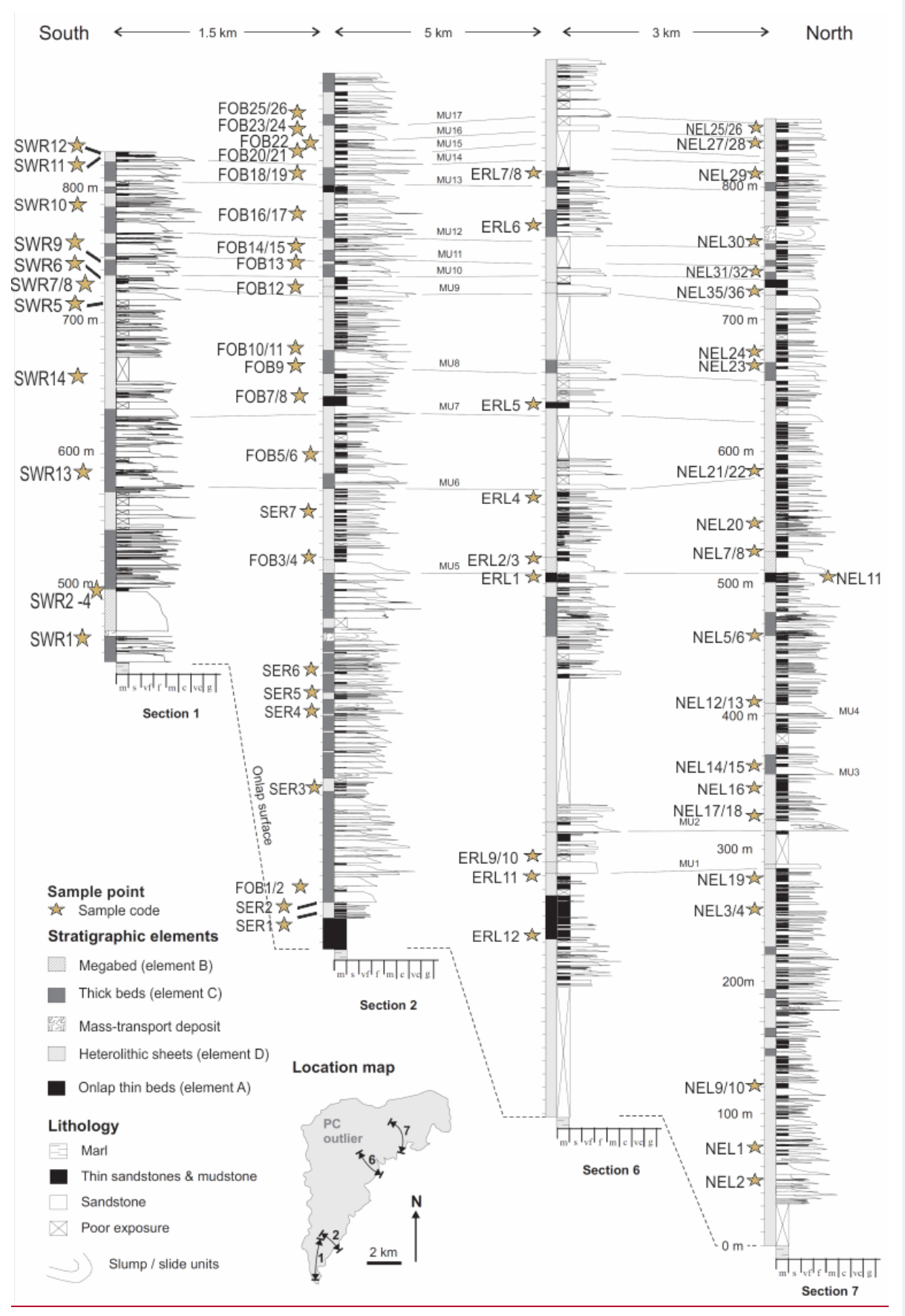




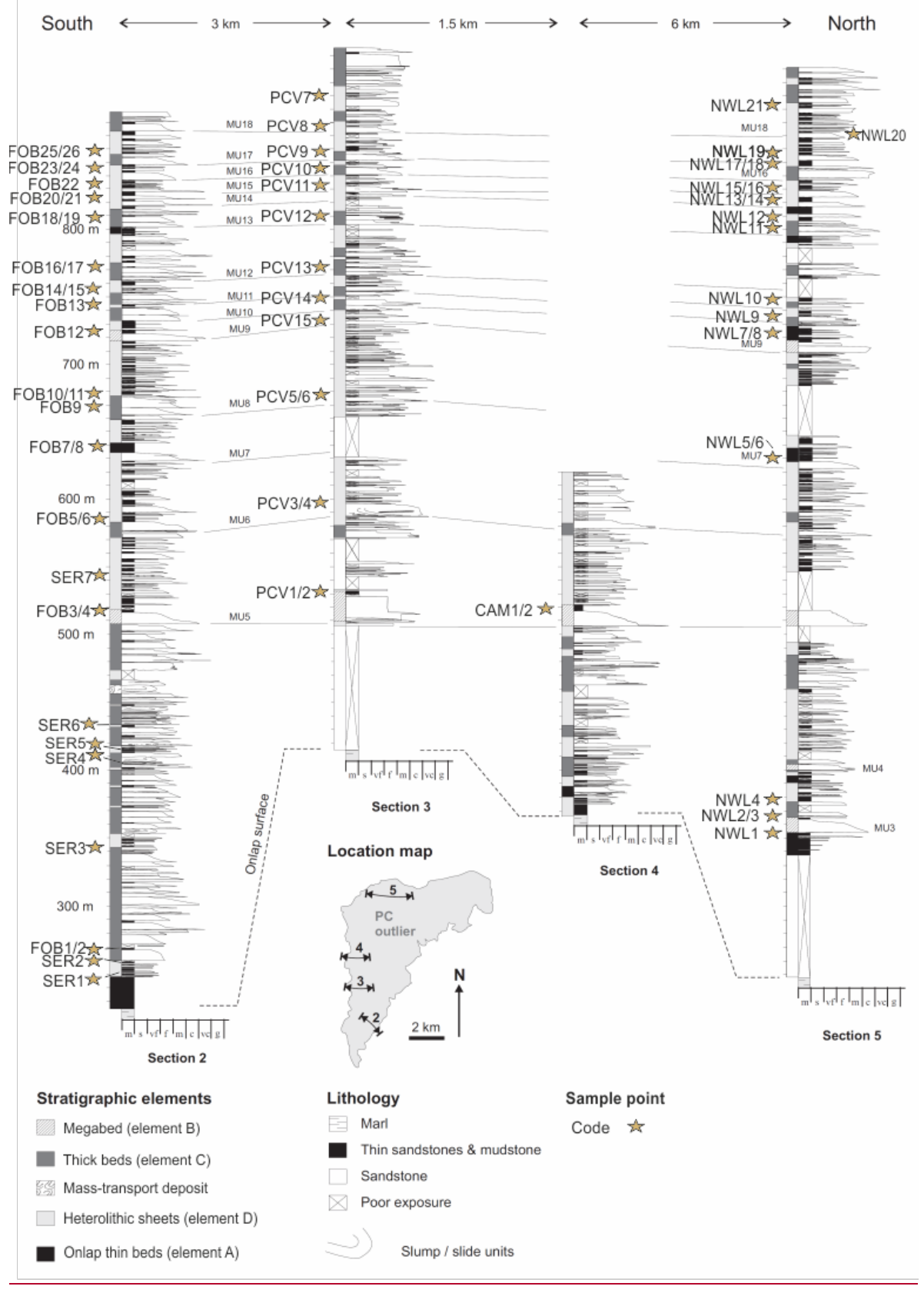



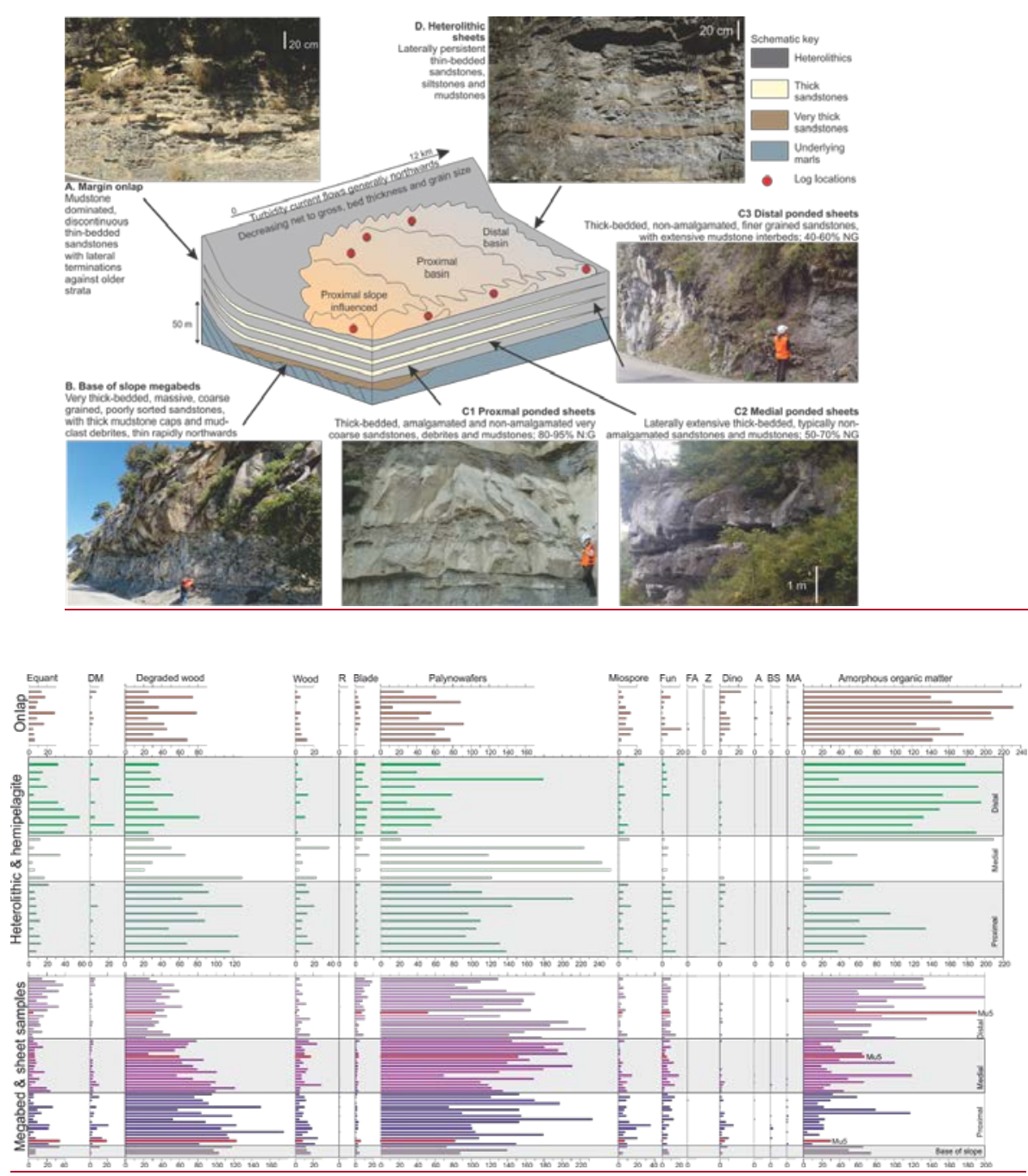


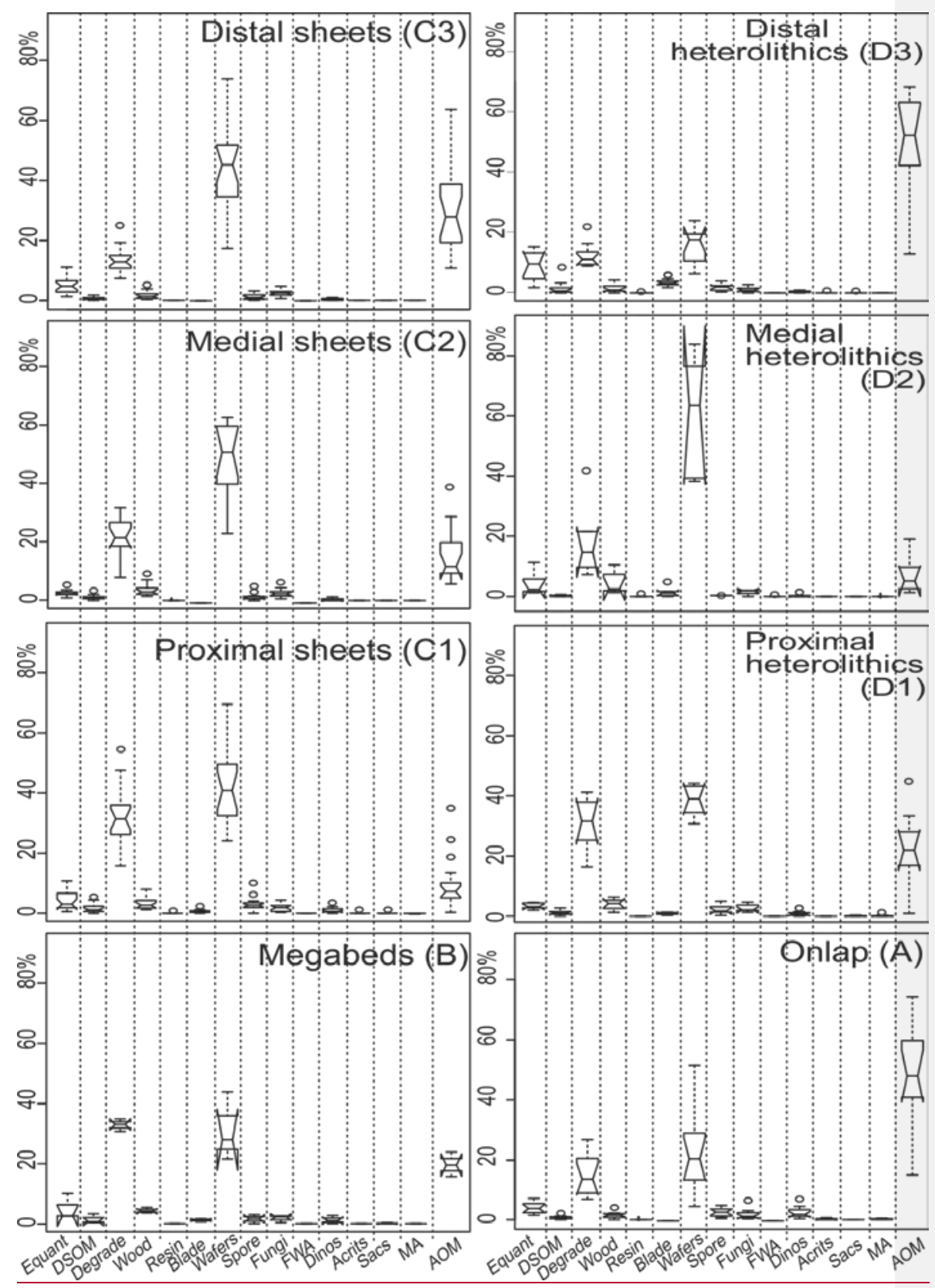




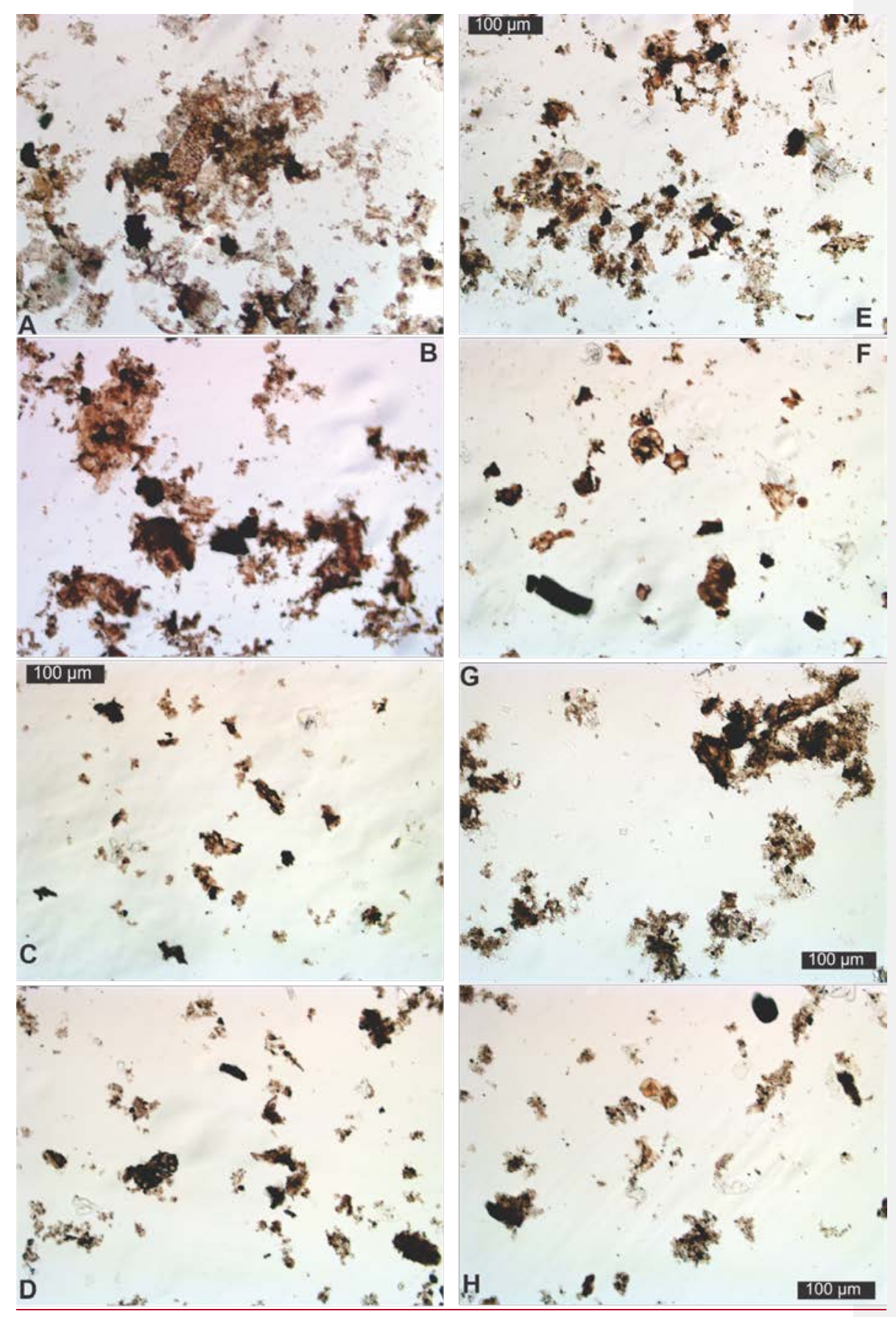



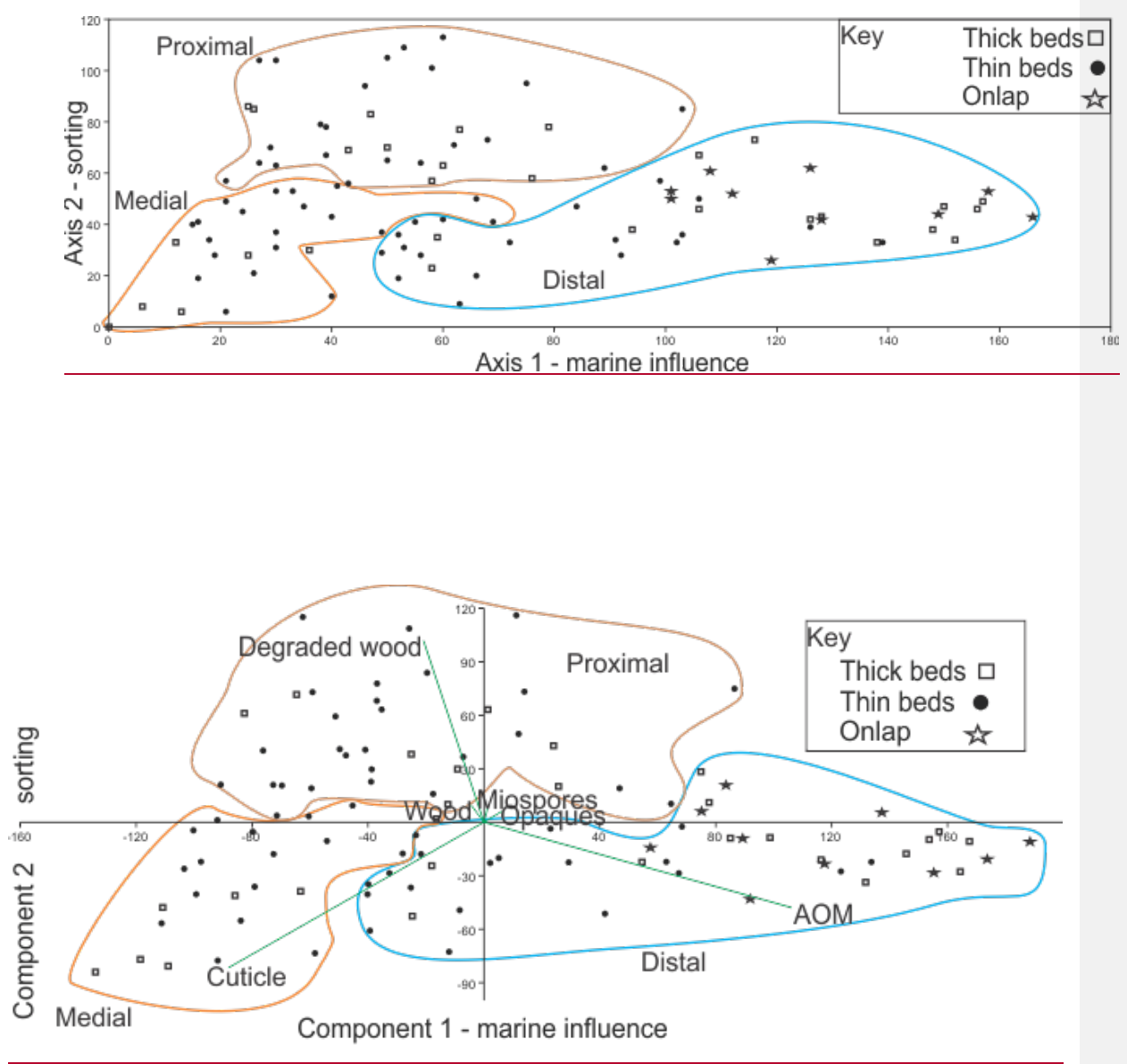


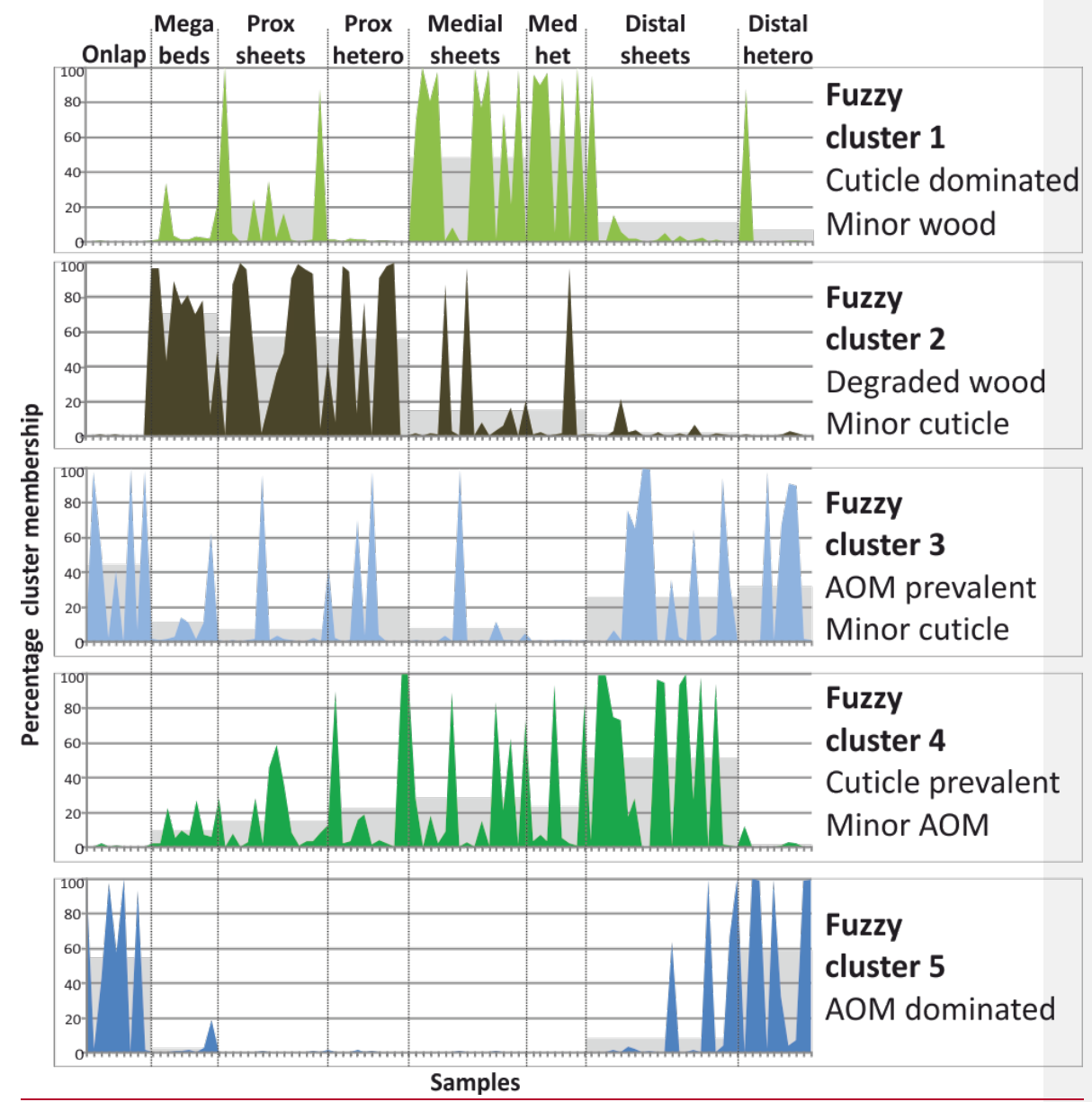




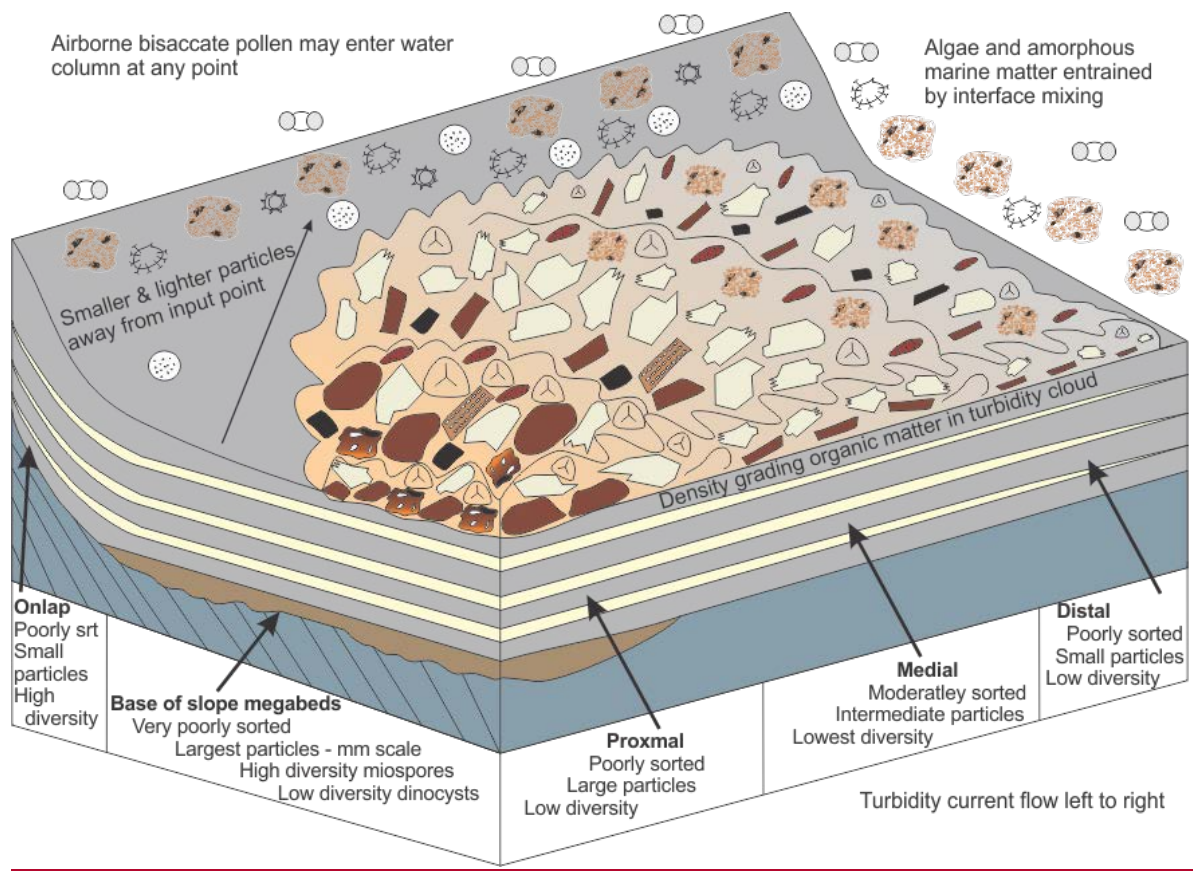

